

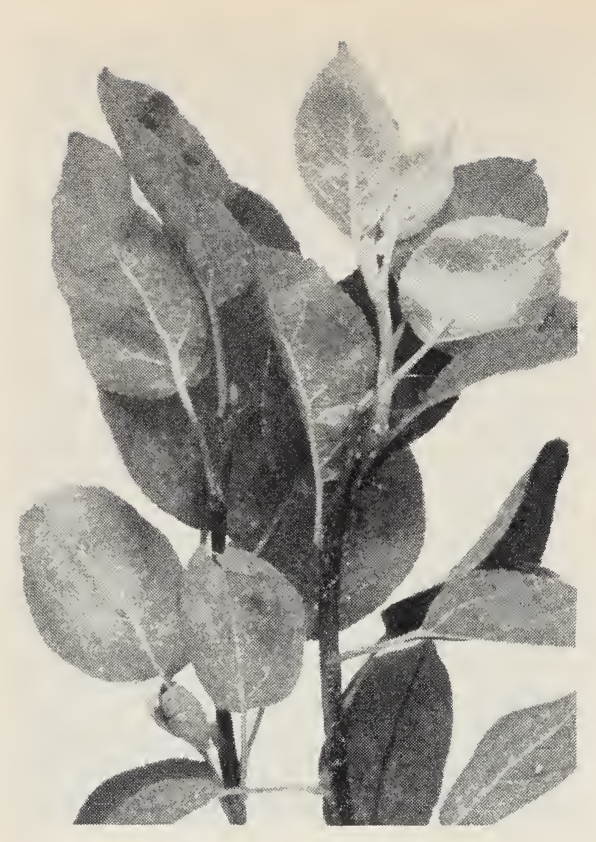

Fig. 1. Two apple shoots cut back on May 29, when they were both growing at the tip, and photographed on July 7, 1936. Left: shoot was cut back to a full-grown leaf on rather hard wood; end bud remaining was far into the rest period. Right: this shoot was growing more than the shoot at the left, and was cut back to a leaf two-thirds grown on rather succulent wood; the end bud remaining was not too far into the rest period for the wound stimulus and the end position to cause growth.

\section{During California Winters temperatures rarely drop low}

enough to kill deciduous wood or buds. Instead, the relatively warm temperatures tend to prolong the rest period during which buds will not expand into flowers or leafy shoots. Orchardists sometimes help to end this rest period by spraying with oil or oil fortified with dinitro compounds, after a moderate amount of chilling. The most promising solution to the problem, however, is in developing varieties tolerant of mild winters.

This Circular Summarizes the results of research on the chilling requirements of various deciduous species previously reported in Bulletin 611 and discusses the probable causes and function of the rest period.

THE AUTHORS: W. H. Chandler is Professor of Horticulture and Horticulturist, Emeritus, in the Experiment Station, Los Angeles.

Dillon S. Brown is Assistant Professor of Pomology and Assistant Pomologist in the Experiment Station, Davis. 


\title{
Deciduous Orchards in California Winters
}

\author{
W. H. Chandler - Dillon S. Brown
}

Winters in California orchard districts give greater safety from cold damage than winters in many other sections of the United States. Temperatures are rarely low enough to kill wood or buds; in fact, they are usually high enough to delay flower opening until danger of spring frosts is greatly reduced. Except in young, late-growing fig and walnut trees, damage to wood or buds in decidu. ous orchards by winter freezes is almost unknown. And frost damage to flowers or fruits of most deciduous kinds, except the apricot and the almond, is so rare that the peach crop-hazardous in colder districts-is almost as dependable here as the corn crop in Iowa. True, there are frosts, but flowers of most deciduous orchard kinds tend to open too late in spring to be damaged. This delay in opening of flowers is caused by winters that are too warm to break the rest perioda condition developing in both leaf buds and flower buds in late summer that prevents their opening until they have been chilled for a period at temperatures below $50^{\circ} \mathrm{F}$, with temperatures of $40^{\circ}$ or lower the most effective.

\section{The Rest Period in Deciduous Orchards}

Buds of deciduous fruit trees enter a state of rest shortly after being formed. While in the rest period, buds will not expand into flowers or leafy shoots. After exposure to sufficient winter cold, the rest influence is ended and buds will develop normally whenever growing temperatures prevail.

By the time a leaf on a deciduous tree is full grown, or a little later, the bud in its axil goes into the rest period. Earlier, the bud's growth was prevented by a substance moving down from the tip of the shoot. In the rest period, even though the shoot is cut back to the bud so that it can receive no new supply of this inhibiting substance, the bud will not grow until the following spring. For example, parts of two apple shoots are shown in figure 1, photographed on July 7 after being cut back on May 29. The shoot at the left was cut to a full-grown leaf where the wood had become rather hard, although the shoot tip was still growing. Neither this bud nor any below it grew until the following spring. The shoot at the right was cut back to a leaf only about two-thirds grown, that was attached to rather succulent wood; the uppermost bud soon started and by July 7 had made the light- colored growth that shows with 3 or 4 leaves.

In other words, some buds on a tree may be in the rest period by 5 to 7 weeks after spring growth starts. If the tree has no shoots longer than about 1 foot, the last buds may be in the rest period before July 1. On young trees or trees pruned severely and given an abundant nitrogen supply, some buds near the tips of long shoots may not be in the rest period before September. Cambial growth in the top ceases soon after most of the shoots have stopped elongation. Roots seem to have no rest period and grow most rapidly after food from the leaves ceases to be used for shoot and cambial growth in the top.

By the time the leaf at which a bud is located is full grown, or a little later, the chemical processes have begun that will determine whether it will produce a 


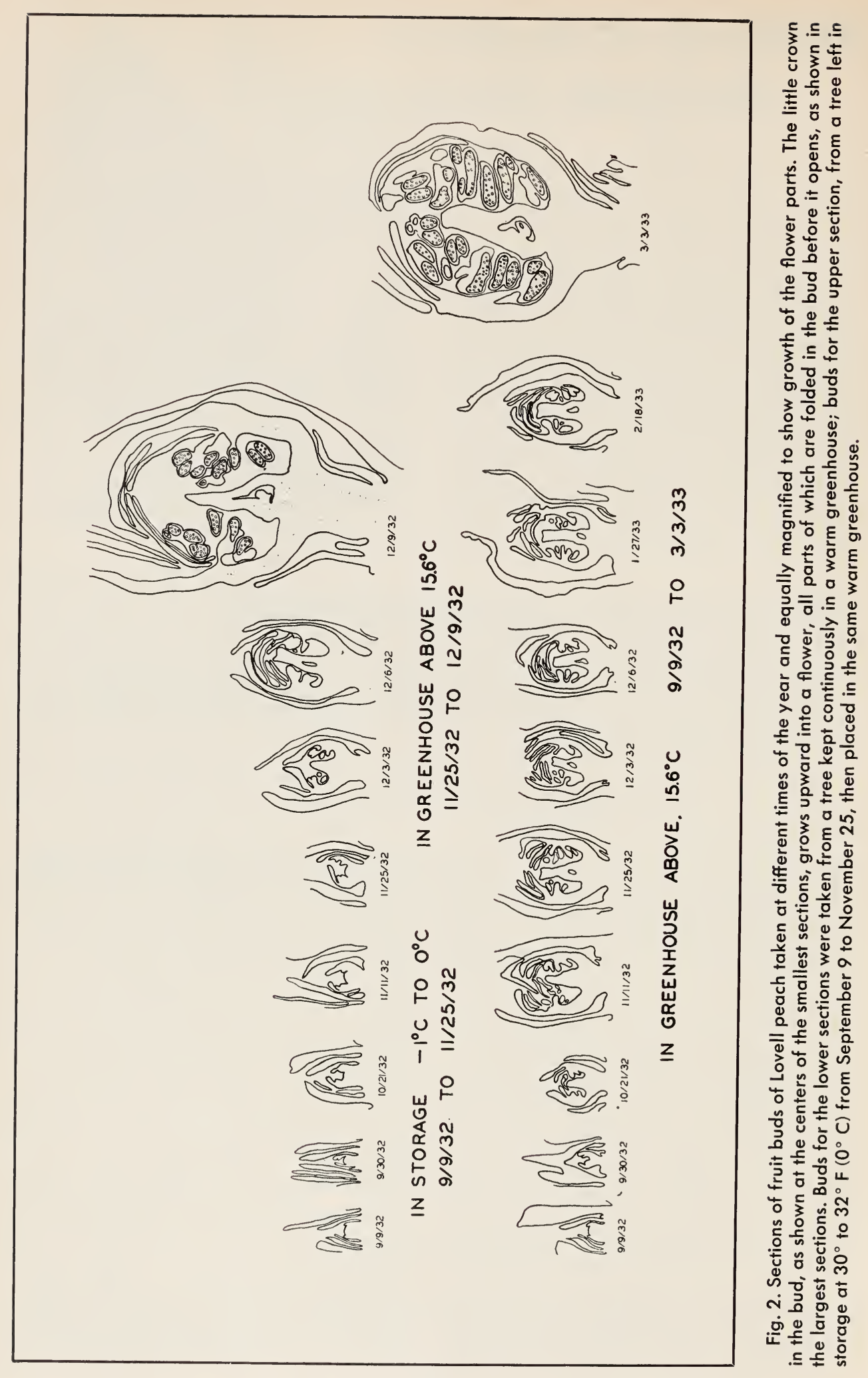


shoot or one or more flowers in the following spring. A few weeks later the first evidence of flower formation can be detected by microscopic study. In the oldest buds on the tree, this may be as early as June 20. In the youngest buds on long shoots it may be as late as September. Flower parts develop slowly in the bud during the following winter.

This development is greatly retarded by the rest period, as the bud sections in figure 2 show. The buds in the upper row are from a peach tree that was in storage at $30^{\circ}$ to $32^{\circ} \mathrm{F}$ from September 9 to November 25 and then in a warm greenhouse. Those in the lower row are from a tree that was continuously in a warm greenhouse. After being chilled adequately, buds in the upper row advanced as much in 14 days as the unchilled buds in the lower row in 133 days.

Complete opening of flower buds in spring is delayed by inadequate chilling nearly as much as that of leaf buds. If the chilling is highly inadequate, many flowers may fall before they are fully open; on trees of some kinds many flower initials may die in the buds before they begin to open. If these are mixed buds, like those of the apple and pear, each with a cluster of flower initials and one or more shoot initials, a bud may produce only a leafy shoot or a leafy shoot and a reduced number of flowers. If they are flower buds, such as those of the apricot or plum, with only a flower or flower cluster in each, dying of the flower initials causes the buds to fall. Sometimes too few buds are left to produce a fair crop.

\section{Length of Rest Period}

The rest period in a bud does not have a fixed length. The time of its ending depends on variety, length of shoot growth, and amount of winter chilling.

If the winter is as warm as it sometimes is in parts of California, buds on vigorous young trees of some varieties may not grow until the middle of the following summer-and then only a small percentage will grow.

Figure 3 is of a Northern Spy apple tree in Berkeley on June 18, after an especially warm winter. Only a few shoots were growing and these did not start until late May and early June. On several of the twigs no buds grew until the following spring. The rest period (condition) of these buds lasted nearly two

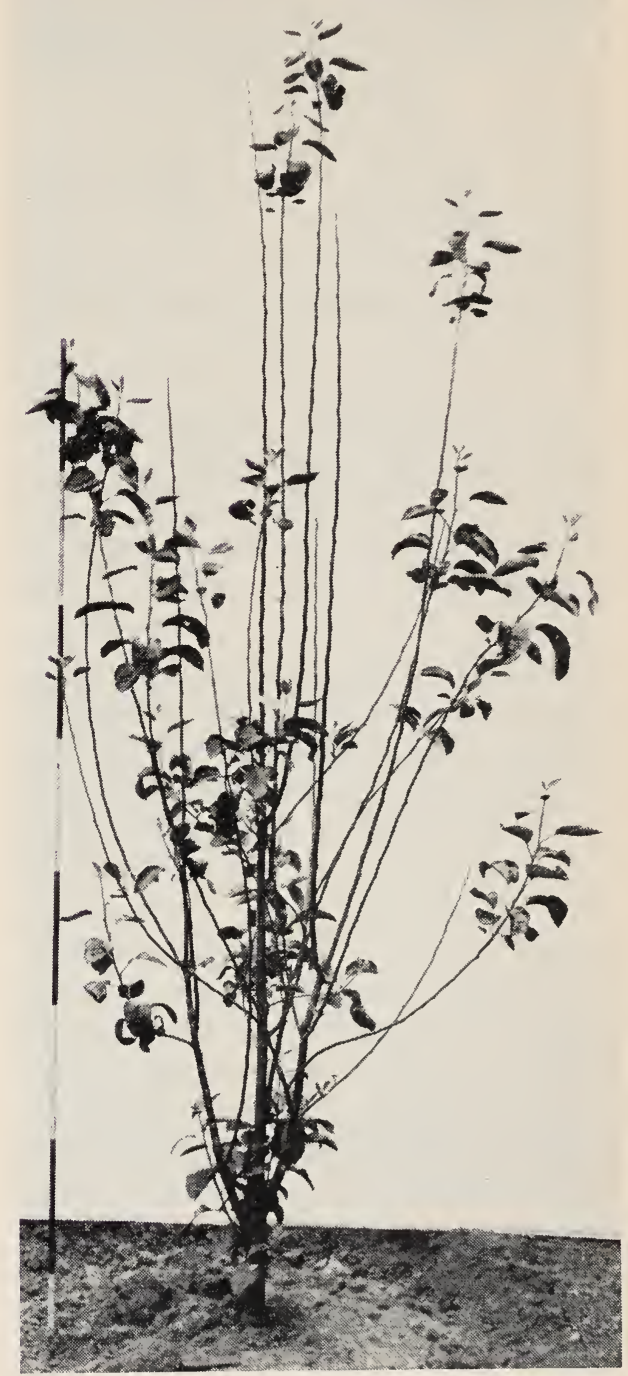

Fig. 3. Northern Spy apple tree photographed June 18, 1930, in Berkeley, to show greatly delayed, uneven growth from the buds after an especially warm winter. 
years. If this Northern Spy tree could have been held at a temperature of $40^{\circ} \mathrm{F}$ or lower, beginning about November 1 , the buds would have been able to grow by January or a little later. The rest period would have been about 6 months.

After leaf fall, changes proceed in the buds that gradually release them from the rest period. These changes are faster at about $40^{\circ} \mathrm{F}$ than at higher temperatures, but apparently are not faster at freezing temperatures than at $40^{\circ}$ or a little lower. Different kinds of trees and different varieties of the same kind require different amounts of chilling to release the buds from the rest period. Buds will start growth before the rest period is completely broken, but their earliest development will be rather slow; something in them is impeding their growth. After a few leaves are open, however, growth of the shoot may be as rapid as though the rest period had been completely broken before the bud began to open.

In the warmer coastal districts, it is usually warm enough for some growth during the entire winter, except for short cold waves. Nevertheless, growth does not begin whenever the weather is warm, unless the rest period has been broken. For example, the English Morello cherry branches shown in blossom in figure 4 are of grafts set two years before. On the scion at the lower left, which was set early in February after being held 2 months at $32^{\circ} \mathrm{F}$, leaf buds and flower buds opened more than a month earlier than buds on other parts of the tree that had had only such chilling as a mild winter in the Berkeley hills would supply.

In most deciduous orchard districts of California there is insufficient winter chilling to break the rest period completely. Some rest influence is retarding the buds when they begin to open, and many buds may be prevented from opening so that the number of leafy shoots is reduced. In the part of interior California north of the Tehachapis, winters are rarely too warm to permit growth of enough shoots to produce an abundant leaf surface and large crops. In the southern part of the state and sometimes in the warmest central coastal districts, however, lack of chilling may be so great that only a small percentage of the buds ever open, the first of these considerably later than in northern California and the last as late as midsummer. The total leaf surface on the tree may be much less than on trees of the same variety on as good soil in northern California.

\section{Probable Cause of Rest Period}

The rest period appears to be influenced by chemical processes within the buds, probably controlled by an enzyme or hormone system.

Some chemical influence must keep the buds from opening early in the rest period, and impede their opening after the rest period is partially broken. Growth of some seeds is retarded by a physical influence, such as an impervious seed coat. No such influence seems to retard bud growth. The fact that chemical treatments too weak to influence the physical nature of a woody covering (even substances forced in through the sapwood) will help toward breaking the rest period indicates that entering and emerging from it are chemical processes. The fact that the active substance in the processes must be present in such small quantities that it is not easily identified in the buds suggests that the processes must be controlled by enzymes or hormones.

One suggestion is that chilling or treatment with an anaesthetic, such as ether, may increase the permeability of the living substance, protoplasm, so that an enzyme such as diastase can more readily penetrate to an insoluble food substance such as starch and change it to a soluble form such as sugar. Plant tissue, however, certainly has the ability to change starch to sugar rapidly while the buds are deep in the rest period.

A much more convincing explanation seems to be that during the rest period 


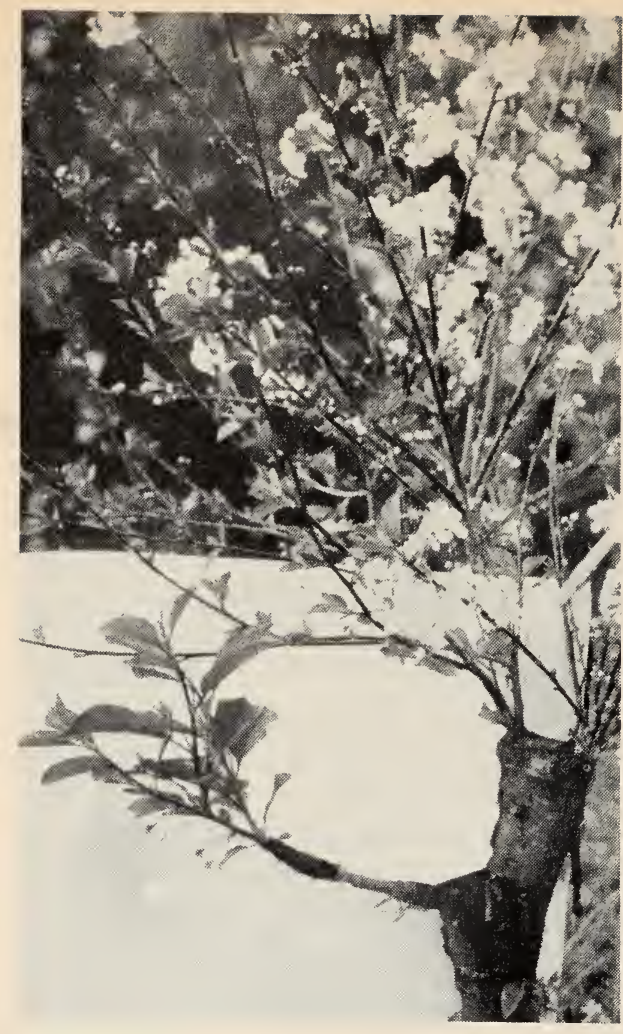

Fig. 4. English Morello cherry tree, April 5, 1936. Lower left: growth from a scion that was set early in February after being held at $32^{\circ} \mathrm{F}$ for two months; its leaf buds and fruit buds opened more than a month earlier than most of those on the remainder of the tree, which had the chilling supplied by the warm Berkeley winter of 1935-36.

growth of the buds is prevented, or greatly impeded, by a hormone. We can now be certain that growth of buds along a growing shoot is inhibited by such a hormone moving down from the tip, auxin (indole-acetic acid) or a closely related substance. Some evidence sug. gests that this substance becomes changed or bound in a form that does not readily move away from the buds. The amount that can be extracted with ether seems to diminish as the buds emerge from the rest period during winter. Furthermore, treatment with rest-breaking substances, such as ethylene-chlorohydrin, seems to reduce the amount of auxin in plant tissue. A bound form of auxin may keep the buds from growing during the deepest part of the rest period, and a reduced quantity may retard their opening when the rest period is only partially broken. And chilling or treatment with substances such as those that have been mentioned may promote chemical processes by which the supply of this bound auxin is gradually depleted. However, the evidence for such a conclusion is far from convincing. We do not yet know what chemical processes are involved in the beginning of the rest period of the buds or in their emergence from it.

\section{Function of Rest Period}

The rest influence keeps buds inactive so that they develop hardiness to winter cold and, in some varieties, delays development in the spring until the danger of frosts is past.

If we cannot be certain how trees develop the substance or condition in the buds that prevents their growing in late summer, autumn, or early winter, we can be more certain why they develop it. Nearly all deciduous orchard species, except the fig and possibly the oriental persimmon, originated in districts where winters are cold enough to kill succulent wood and buds. Weather in late summer and autumn tends to be favorable for growth. If the trees were growing then, they would be tender when the first winter freezes begin. The rest period holds the buds and cambium inactive and cold-resistance — hardening — develops through late autumn and early winter.

Soon after cessation of shoot elongation and, a little later, cessation of cambial growth, when the bark will no longer peel, the wood that is aboveground and the buds begin to acquire increased resistance. Unless the trees are young or are very heavily pruned so that they continue shoot growth exceptionally late, wood and buds of most kinds except the fig and the walnut may be able to withstand as low temperatures as any but the most excep- 
tional winters in California coastal and valley districts.

By leaf fall or a little later, the more resistant trees, such as apple, pear, and plum, may withstand temperatures as low as $0^{\circ} \mathrm{F}$, may have much greater resistance than they will ever need in most of California. This may be as great resistance as they develop throughout the winter, unless there is a period of continuous cold. The maximum possible resistance is developed only by rather long exposure to freezing or near-freezing weather. A tree of a variety such as Wealthy apple growing in a California coastal district may never develop resistance to a temperature lower than about $-7^{\circ} \mathrm{F}$, and in a cold climate such as New York or Michigan may become able to withstand $-30^{\circ} \mathrm{F}$ or lower. And if winter twigs from an apple tree in California are held in storage at $25^{\circ}$ to $30^{\circ} \mathrm{F}$ for a month or two, they may become able to withstand $-18^{\circ}$ to $-20^{\circ} \mathrm{F}$ or lower. If a tree grows late enough for the twigs to become rather succulent when frosty weather begins, it may still develop nearly maximum resistance to cold for the variety by midwinter, if the temperature in late autumn and early winter remains near the freezing point most of the time but does not fall low enough to kill during this delayed hardening process.

This increased resistance to cold as a result of exposure to moderately cold weather is due, in small part, to change of starch in the wood and buds to sugar and possibly to fats, but is due much more largely to changes in the physical nature of the living protoplasm. Very interesting studies at McGill University have shown that exposure to a harmless degree of cold causes protoplasm to become more permeable to water and possibly to other material, and to be able to withstand greater loss of water without losing its fluid nature, without becoming brittle and easily injured.

Although the rest period is very important for the beginning development of cold resistance in autumn and early winter, the kinds of trees that can develop the greatest resistance to cold do not always require the longest chilling to break their rest periods. Siberian crab trees are among the few kinds of trees most resistant to cold; they have such short chilling requirements that in southern California their buds open early and satisfactorily after the warmest winters. If the rest period will prevent their growing and becoming succulent in autumn, a Siberian winter will tend to keep them dormant until spring. The rest period of almost any kind of plant is likely to be completely broken by midwinter in districts as far from the equator as latitude 43 to 45. The Bartlett pear and some varieties of peaches and walnuts have very long chilling requirements and yet are only moderately resistant to low winter temperature. Perhaps the longest chilling requirements might be expected in buds of kinds that originated in districts where winters are only moderately long but are likely to have killing nights following warm periods. If the rest period continues through most of the winter, it will keep the buds and the cambium from becoming active and tender during warm periods, to be killed by a cold night following.

Forms that originate in districts where a long chilling requirement would be a handicap-as in southern Californiausually have short chilling requirements. For example, some forms of the North American papaw, Asimina triloba, found in Indiana, that have exceptionally long chilling requirements, sometimes stay dormant two years in Berkeley, while forms found in southern Arkansas grow and fruit fairly well in southern California. And forms of the pecan found wild in Mississippi have short chilling requirements, while forms found wild in Indiana have longer.

On pages 18 to 37 the chilling requirements of the different orchard species for California are discussed. 


\section{Treatments That Help Break the Rest Period}

Sprays with oil, or oil fortified with dinitro compounds sometimes help to end the rest period after a moderate amount of chilling weather. Breeding for varieties tolerant of mild winters is the most promising approach to the problem in areas in which mild winters are the rule.

Many treatments given after plants have had a month or more of chilling following leaf fall will complete, or at least advance, the process of breaking the rest period, so that buds can open a little sooner.

Exposing to Chemicals. Among the oldest treatments is exposure to an atmosphere containing a little ether, chloroform, acetylene, or ethylene. Smoke may have this effect weakly, probably because of ethylene or related substances in it. Exposure to chemicals is not really effective, however, except on plants or plant parts in a gas-tight container.

Pruning. A wound made close to a bud after a month or more of chilling following leaf fall will hasten its opening after a warm winter. Pruning at this time tends to shorten the rest period of buds a little, although pruning in summer has the opposite effect. On the whole, pruning wounds are not very effective in shortening the rest period.

None of these treatments is effective when given during the most profound part of the rest period-late summer and autumn before leaf fall. In fact, they are not effective after leaf fall until the buds have had some chilling. And they tend to delay opening if given after the buds have had chilling enough to break the rest period completely.

Spraying. A number of spray treatments have shown some promise in the orchard. Oils used for insect control about 4 to 6 weeks before the buds should normally open in the district have sometimes caused them to open a little earlier and all more nearly at one time.
Certain newer insecticides in oil are considerably more effective in shortening the rest period than sprays of oil alone. One of these is known as DNO (dinitroo-cyclohexyl phenol). A spray containing 0.06 per cent of this material in water $(2$ per cent of an oil containing 3 per cent of DNO) has hastened blossoming and leafing of a number of kinds of orchard trees after warm winters. DNC (3-5-dinitro-ocresol) at 0.06 per cent strength (4 per cent of an oil, containing 1.5 per cent of DNC) seems to give as good results or slightly better on apple and Mayflower peach trees at least.

The longer the chilling requirement of the variety and the warmer the winter, the later in winter or spring the spray must be given to be even moderately effective. In an average winter at Riverside, for example, the best time to spray Wickson or Kelsey plum or Royal apricot trees may be about January 25 to February 5, Elberta peaches or Tilton apricots about February 15, Gravenstein apples about February 20 to March 5. After a cooler than normal December and January, the best time may be about a week earlier; and after an especially warm December and January, a week later.

For reasons that have been discussed concerning uncertainty in efforts to determine the degree to which the rest period has been broken, it may never be possible to know precisely the best time to do the spraying. Fairly close estimates can usually be made, however, from temperature records for December and January, especially after the grower has had several years of experience in spraying with $\mathrm{DNO}$ or DNC, or has followed experience in other districts with the same varieties that he grows.

Trees of some varieties, such as Santa Rosa plum, will rarely need the spray to cause the setting of a fairly good crop in most of southern California. Those of certain other varieties will not respond well to the spray unless the winter has supplied a little more than the average 
amount of chilling there. These are such varieties as Climax plum, Gravenstein and probably other apples, and most, if not all, varieties of cherries grown at low elevation in southern California. They may show slightly better leafing at the beginning of spring but not enough better to affect growth and yield measurably. In other words, the spray seems to increase the yield measurably only on trees that have had nearly enough chilling to permit a fairly good opening of leaf and flower buds without it. And the spray seems never to cause trees at low elevations south of the Tehachapis to blossom or ripen their fruit as early or to yield as much as trees of the same variety grown in the San Joaquin Valley. It is not likely to enable an orchard of trees with a long chilling requirement in these counties to compete in early markets with fruit of the same variety from the San Joaquin Valley. Furthermore, it is not likely to cause trees with a long chilling requirement to yield as well in these southern counties as trees of as good a variety with a short chilling requirement.

A grower in one of the southern counties who has an orchard of trees (other than walnuts or cherries) that have their yield and quality of fruit reduced by inadequate chilling may find a spray with DNO or DNC advisable in some springs, when the weather has been especially warm in December and January; but he will probably not find it advisable to plant trees of such a variety with the expectation that spraying with DNO or DNC will make them yield well enough to compete with orchards of the same variety farther north.

DNO sprays are considerably weaker in their influence on buds partly in the rest period than ether or ethylene in a closed container. In one spring, Gravenstein apple trees were covered with tents under which lemons inoculated with green mold released ethylene in harmless quantities for 2 weeks in February. These trees opened their leaf and flower buds in spring almost as though the chilling requirement had been completely satisfied, considerably better than trees sprayed with DNO, and much better than trees under a tent without the moldy lemons. Such a treatment, however, entailing special equipment over an entire orchard, would be too expensive for practice.

Breeding Varieties Tolerant of Mild Winters. In a number of kinds of fruit trees, varieties are now being developed that produce fruit of high quality and have chilling requirements short enough to enable them to grow and yield in the southern counties. These perform better than trees of varieties with long chilling requirements, which have been given a DN spray. Breeding for such varieties seems much the most promising way of maintaining a deciduous orchard industry in districts with warm winters.

\section{The Importance of Winter Chilling}

The guide for estimating the effectiveness of winter chilling on certain buds is based on a determination of length of exposure under controlled conditions.

The exact temperature at which the rest period is broken most rapidly is not known for many kinds of buds-if for any-but temperatures from below freezing up to about $40^{\circ} \mathrm{F}$ are found to be highly effective for many kinds. The length of exposure to a given chilling temperature, such as $32^{\circ}$ or $40^{\circ} \mathrm{F}$, which will enable the buds on trees of a variety to open freely at growing temperatures may be learned fairly accurately if the trees are kept under controlled conditions so that the buds will be certain to have the same temperature as the air. The results 
of such determinations under controlled conditions have been applied as a guide in estimating the effectiveness of periods of chilling temperatures in the orchard.

\section{Local Influences on \\ Effectiveness of Chilling}

The adequacy of winter cold in ending the rest period is affected by the intensity of sunlight, fog or cloud, wind, and tree condition.

In the field, bud temperatures frequently may be higher than the temperature of the air, especially during the day. Consequently, the effectiveness of a given length of exposure to chilling temperatures in the orchard may differ from that indicated by controlled tests, so that orchard temperature records cannot be relied on to give completely dependable information concerning the degree to which buds of a variety have been released from the rest period by a given date in winter or spring. Intensity of sunlight influences the bud temperature during daylight, and the nature of the summer and autumn influences the chilling requirements of the buds at the beginning of winter.

Sunlight. In fairly intense sunlight, exposed wood and buds receive more heat than they radiate, and have a temperature above that of the air and above that of wood and buds in the shade. The higher temperature during sunlight may influence considerably the degree to which the buds are released from the rest period during a warm winter. In figure 5, above and below, are Elberta peach trees photographed at Ontario on April 7, 1934. The upper trees were just north of a tall eucalyptus hedge that offered shade during sunny winter days. The lower ones were too far from the hedge to receive any shade. The upper ones were nearly in full leaf, the lower ones just showing green points from the buds. Because of this earlier leafing and growth of shoots from more buds each year, the shaded trees were considerably larger than the others, in spite of root competition from the hedge.

Fog or Cloud. A hazy, foggy, or cloudy sky will have the same effect as the hedge in keeping the temperature of the buds down to that of the air; the obscured sky may also keep the air cooler than would clear sunlight. Tule fogs in the great valleys tend to insure adequate chilling for buds of most varieties.

Wind. A fairly strong wind will tend to keep the temperature of wood and buds down to that of the air, or nearly so. Winter air temperatures tend to be higher near the ocean than at interior positions. Nevertheless, an orchard located so that it receives the daily ocean wind in full velocity may open its buds a little earlier and better in spring than one with a slight ridge between it and the ocean, provided the winter is so warm that the time of bud opening is determined almost entirely by the degree to which the buds are released from the rest period.

\section{Vegetative Condition in Autumn.} Another confusing influence on spring behavior of trees after warm winters is their vegetative condition in autumn. Buds on long, late-growing shoots require more chilling to enable them to open well at the normal time in spring than buds on weaker shoots. In some varieties after warm winters, buds on long water sprouts of the preceding summer may be just opening or still unopen when weaker branches on the same tree have fruits more than a half inch in diameter and new shoots with basal leaves full grown.

The long shoots that grow somewhat later because the tree was pruned severely in the preceding spring or winter may also be later in opening their buds after a warm winter; but shoots that grow as much as 18 inches following moderate pruning may not open their buds appreciably later than shoots on unpruned trees. And shoots that are strong as a result of an abundant nitrogen supply may not require appreciably more chill- 

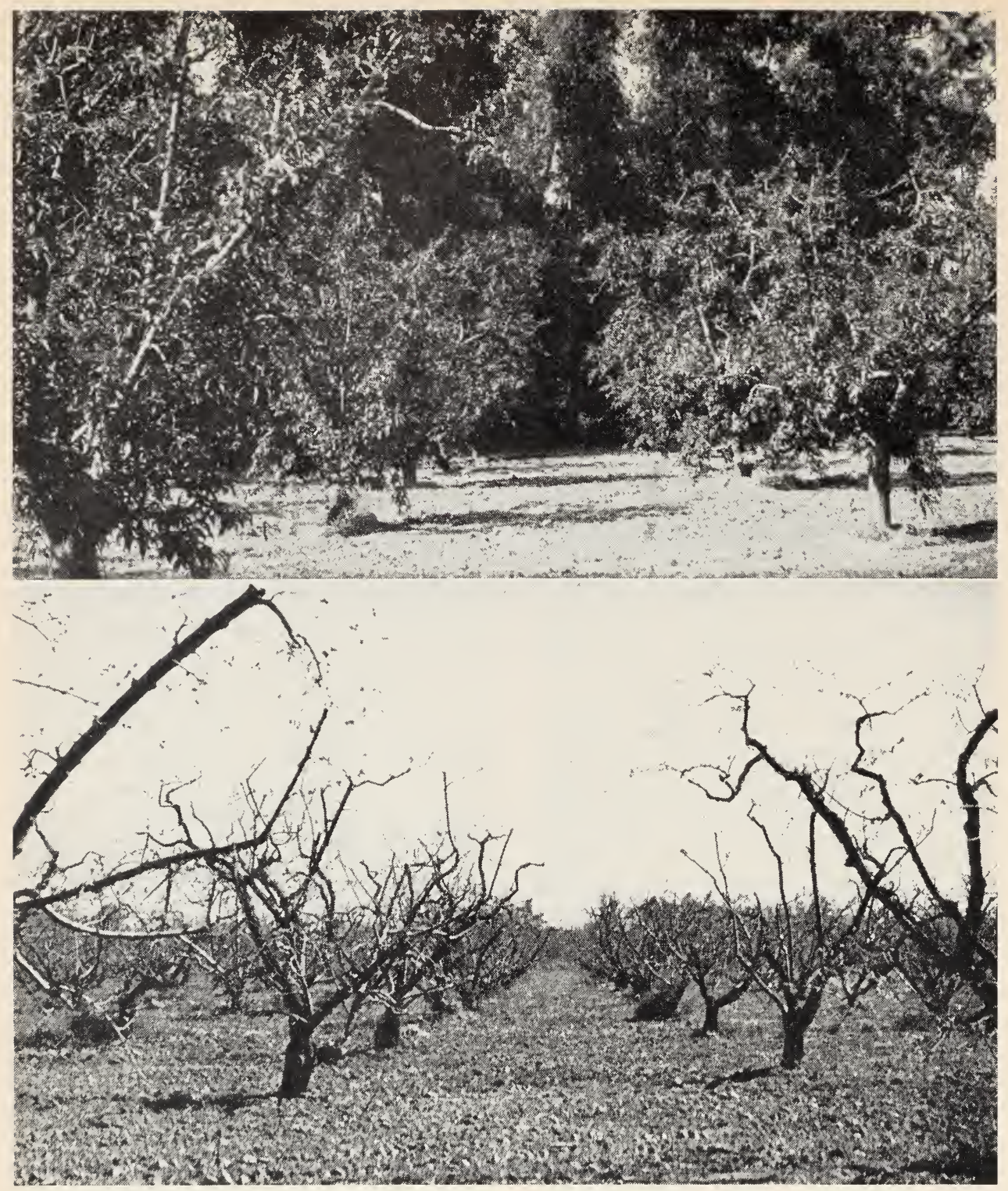

Fig. 5. Elberta peach trees near Ontario, California, April 7, 1934. Upper: trees in full leaf, which were in the shade of a eucalyptus hedge nearly all of each day during the winter months. Lower: trees in the same orchard, which were not shaded during the winter; on these only a few leaves have started to grow.

ing than shoots of fairly weak trees. Buds on trees pruned in midsummer or somewhat later, even though no new growth follows in the same summer, may have their chilling requirements increased so that they open later in spring after a warm winter than buds on trees pruned in the preceding spring or winter.
Deficiencies, such as nitrogen or water, that cause early leaf fall sometimes, although not always, cause the buds to open slightly earlier after a warm winter. If only part of the leaves fall early as a result of a period of very hot, dry air, an early autumn rain may cause those left to hold late and the tree to go into winter in 
a more succulent condition. This resembles the condition following summer pruning, and the chilling requirement may be increased. Opening of buds may be a little later and more imperfect after a warm winter. Withholding irrigation water in late summer may in some years reduce the chilling requirement of the buds so that they can open a little earlier after warm winters; but if an early rain should follow partial defoliation caused by the water deficit, such a water deficit might increase the chilling requirement and cause the buds to open a little later after a warm winter.

\section{Attempting to Predict Spring Growth and Flowering}

Predictions on the sufficiency of winter chilling must be made with the modifying factors of local influences in mind.

In a climate where the amount of winter chilling largely determines how early and how well the buds will open, people sometimes try about February 1 to predict the time and healthiness of spring growth and flowering in different kinds of deciduous orchards. For this they study temperature records for December and January. Some use the number of hours in these 2 months during which the temperature was $40^{\circ}$ or $45^{\circ} \mathrm{F}$ or lower. Such calculations make no allowance for differences in temperature above the basic one. When the sky is hazy or foggy, even though many more of the hours with temperature above the basic $40^{\circ}$ or $45^{\circ}$
F are only a little above, they still may be rather more effective for rest-breaking than if the sunlight were more intense. Mean monthly temperatures may be better, for the whole range of temperatures influences the mean. Whether a low mean is due to colder nights than in other years, or to foggy, cooler days, the mean expresses fairly well the amount of chilling air temperature. A large error in both methods, however, results from differences in amount and intensity of sunlight, when temperature of exposed buds is considerably above that of the air.

Another error seems to be involved. The high temperature of the buds in sunny afternoons does more than reduce the amount of chilling the buds are receiving. Dr. J. P. Bennett found that, for Beurre Hardy pear buds at least, when the temperature fluctuates so that in some hours it is near $70^{\circ} \mathrm{F}$, those hours are not merely failing to advance the buds toward ending their rest periods, but are actually reducing the progress that has been made, increasing the total chilling requirement. Young trees held 71 days with periods of 18 hours at $37^{\circ}$ alternating with periods of 6 hours at $68^{\circ} \mathrm{F}$, required more hours at $37^{\circ}$ in these daily 18 -hour periods than they required when at $37^{\circ}$ continuously; 1,278 hours (71 days) in the 18-hour periods at $37^{\circ}$ did not break the rest nearly as well as 1,248 hours (52 days) at $37^{\circ}$ continuously. Results in agreement with these have been reported in Sweden for a species of water plantain.

\section{Winter Chilling in Some Parts of California}

Trees of very few varieties have chilling requirements too long for fairly satisfactory opening of buds after the warmest winters in the Sacramento and San Joaquin valleys. Buds of many may be delayed somewhat by some remaining rest influence in the spring. This delay is usually a little more pronounced in the San Joaquin Valley than in the Sacramento Valley. In both districts it is much less pronounced than in areas south of the Tehachapi Mountains.

During the years 1917-23, the winters in southern California were cooler than many winters since, and a considerable

number of varieties were planted in commercial orchards that did not fruit well following some of the warm winters after 
AVERAGE RELATIVE HUMIOITYAT 12.00 NOON FOR DEC.,JAN.,FE8., - LOS ANGELES

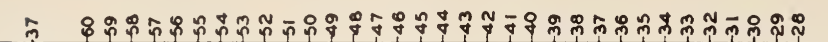

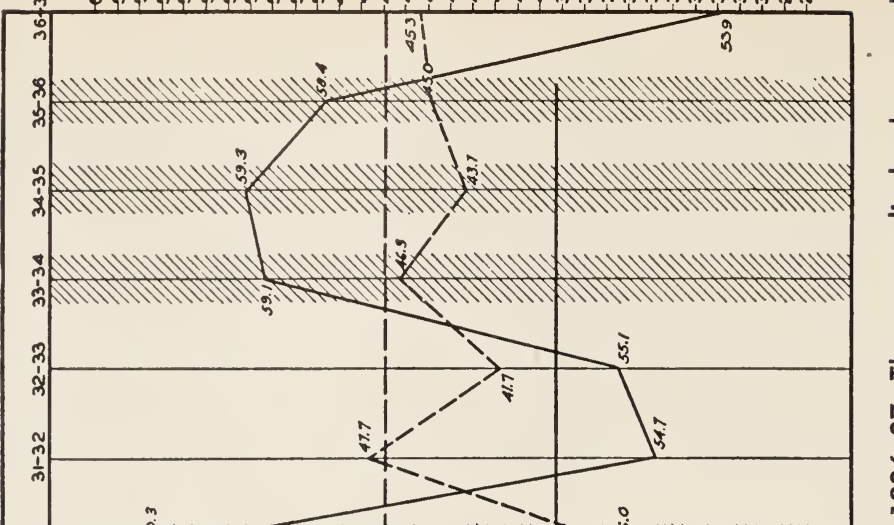

$\stackrel{00}{ \pm}$

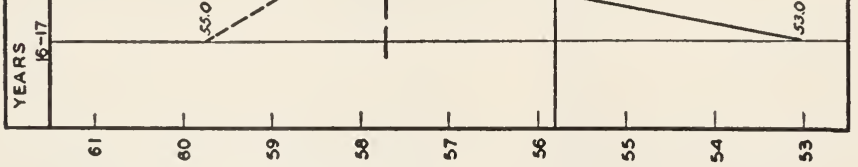

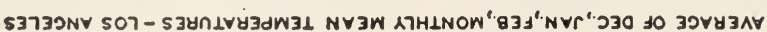




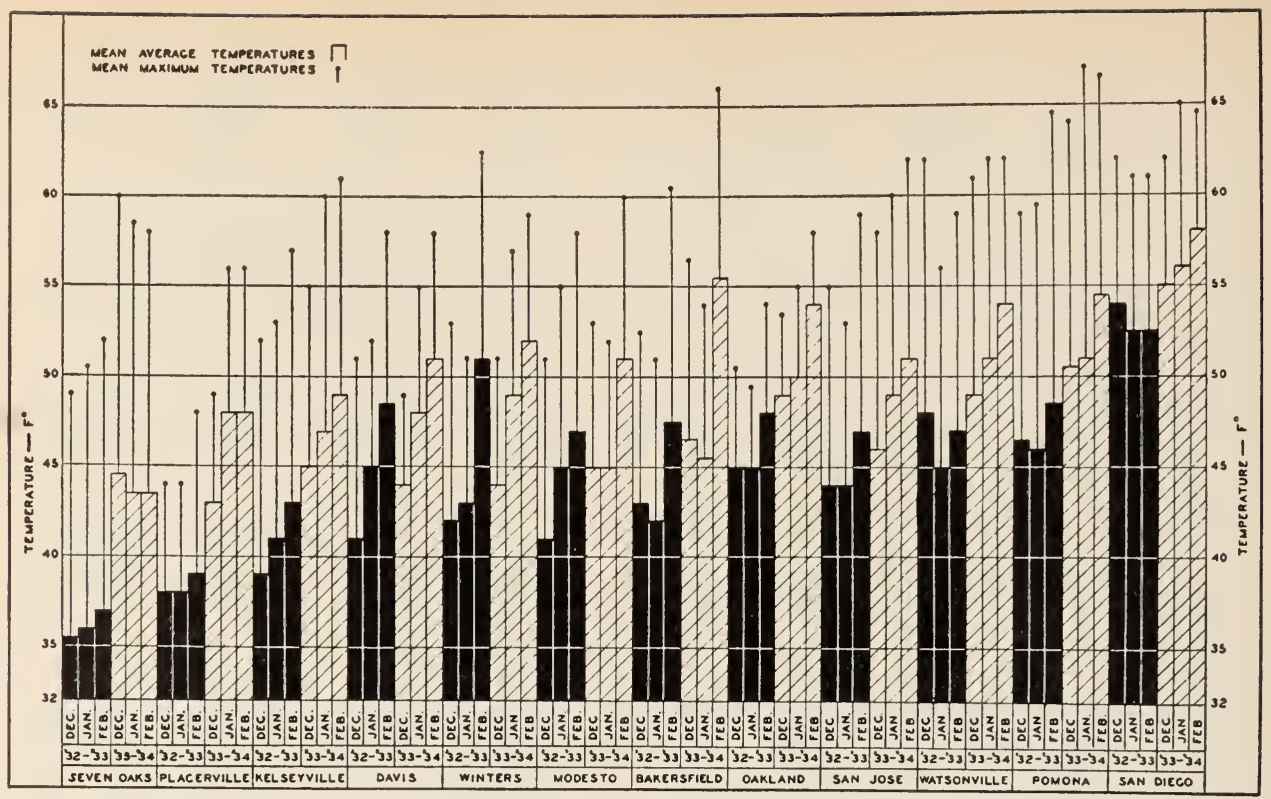

Fig. 7. Black bars: the mean temperatures for December, January, and February, 1932-33. White bars with diagonal black lines: the mean temperatures for the same months at the same places, 1933-34. Circles at top of lines extending from these bars: the average daily maximum temperatures for the same months.

1923. These plantings gave an opportunity to obtain information concerning variety chilling requirements. Figure 6 shows temperature and noon humidity records at Los Angeles for the months of December, January, and February, averaged together for each year from December 1916 to February 1937. The perpendicular bars mark the winters which were followed in spring by striking delay in opening of the buds on deciduous trees. The figure shows that the winter of 193233 was an especially cool one and that of 1933-34 an especially warm one. These winters, therefore, seem to be good examples of what may be expected in different parts of the state.

Figure 7 shows the mean temperatures for December, January, and February in the winters of 1932-33 and 1933-34 at positions in California, two of them at about as high elevation as commercial orchards are feasible. Probably if only the first half of February were included, a better portrayal of the winter chilling period at the different places would be given. In some of the districts the last half of February is likely to have warm spring weather. Davis and Winters represent the warmer part of the Sacramento Valley; Modesto and Bakersfield the northern and southern parts of the San Joaquin Valley. Trees of very few varieties have chilling requirements too long for fairly satisfactory opening of buds after the warmest winters in these valleys, although buds of many may be delayed somewhat by some remaining rest influence in spring, the delay usually being a little greater in the San Joaquin Valley than in the Sacramento Valley.

Temperature records in these valleys tend to indicate the amount of chilling rather closely, more closely than in other areas, for tule fogs and haze during many weeks in winter keep the afternoon temperature of the buds nearer to that of the air than in some of the other districts. For example, in the winter months in 1933-34 the mean temperature in the Placerville district was as low as that at Winters or Davis. Yet at Placerville, 


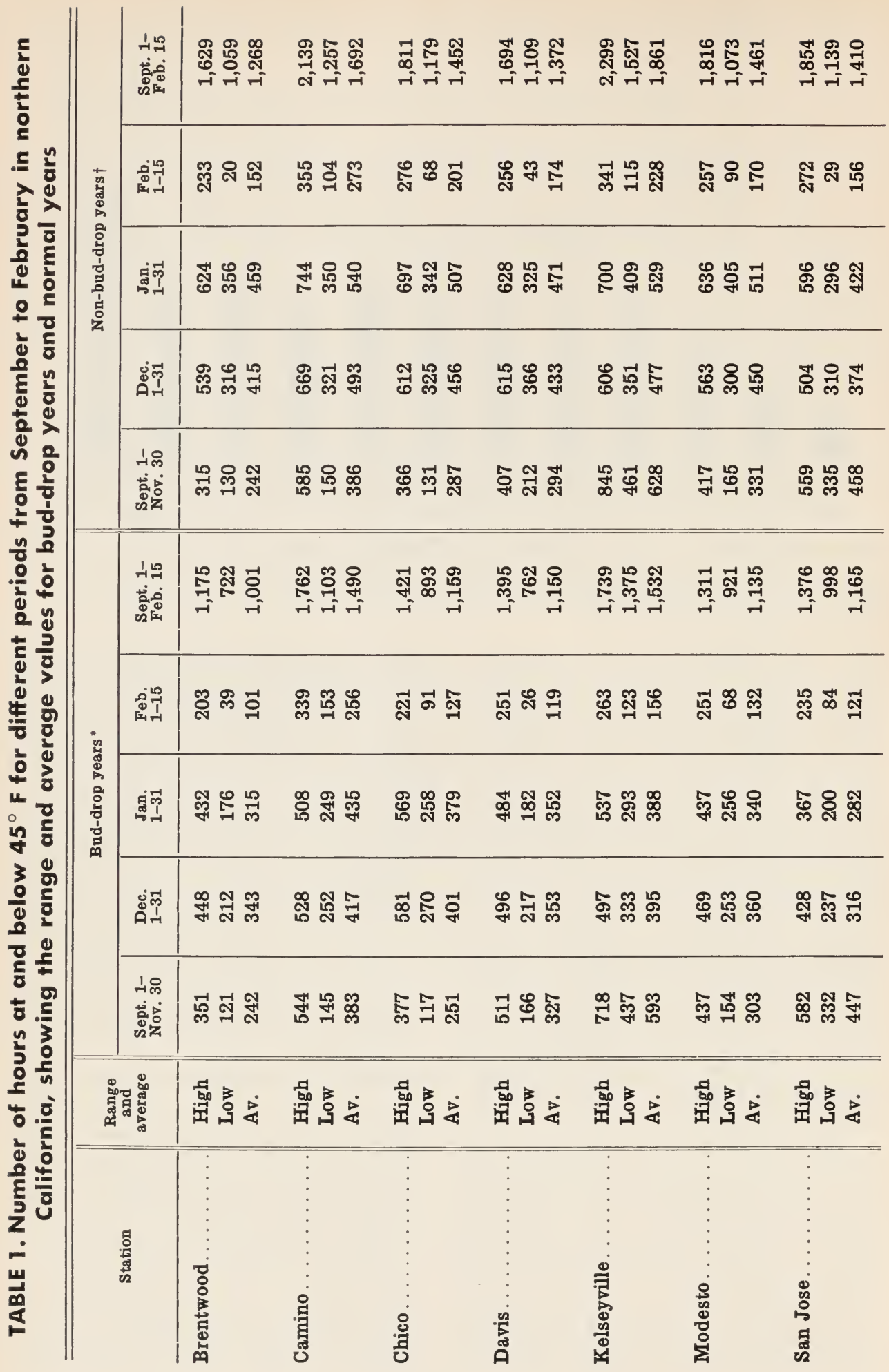




\begin{tabular}{|c|c|c|}
\hline 疍 & 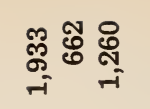 & 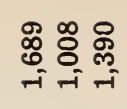 \\
\hline 嵒 & 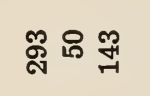 & స్ట \\
\hline 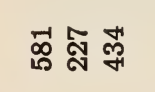 & 哭 。্ল & 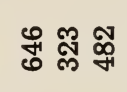 \\
\hline 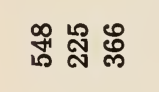 & 움욤 팽 & 总霄总 \\
\hline 桌点虎 & 鹿兽学 & 웜엄 담 \\
\hline 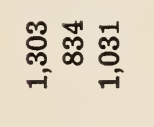 & 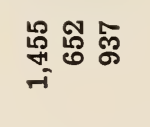 & 휶윰 \\
\hline 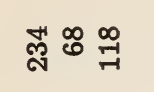 & 웜요 \& & 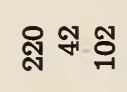 \\
\hline 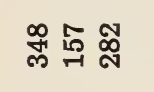 & 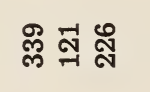 & 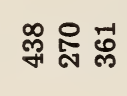 \\
\hline 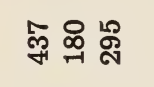 & 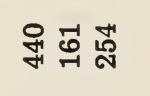 & 总品品 \\
\hline 电恕品 & 丞络。 & 席器일 \\
\hline 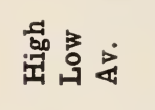 & 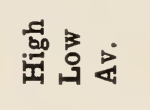 & 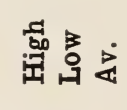 \\
\hline 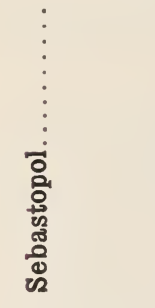 & 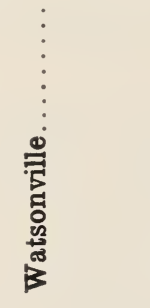 & 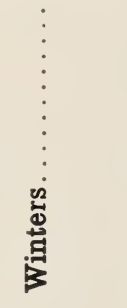 \\
\hline
\end{tabular}

above the winter fogs at 3,000 to 3,500 feet elevation, on sunny slopes down to the area of the tule fogs, Bartlett pear buds were delayed in opening and flowers died in many. Such injury was not shown at Davis or at other areas in the fog belt.

Among these places the lowest mean temperature was at Seven Oaks at 5,000 feet elevation. Yet at Oak Glen, at about the same elevation and latitude, trees of several apple varieties showed injurious delay in opening. The high maximum temperature at Seven Oaks compared with the mean indicates that the sunlight was intense at that elevation. Such delay was not observed at Watsonville, where the mean temperature was considerably higher. Districts at high elevation have a considerable frost hazard, so that varieties with long chilling requirements are safest, even though after the warmest winters the buds are injuriously delayed in opening.

Winter mean temperatures at Watsonville are about as high as at Pomona. Yet near Watsonville is one of the highestyielding apple districts in the world. Yellow Newtown, the variety grown, would probably show much more delay at Pomona. The good spring starting at Watsonville is hard to explain, except possibly that hazy skies and wind keep the daytime temperature of the buds down to about that of the air.

At San Diego the winter of 1932-33 was warmer than either the winter of 1932-33 or 1933-34 at any of the other places. Deciduous fruits in that county are grown mainly at high elevations where the winters are cooler. Only varieties of deciduous fruits with especially small chilling requirements can be grown at low elevation there, except merely as dooryard trees that need not yield well enough to compete with districts having cooler winters.

Dropping of buds during some winters in northern California seems less clearly correlated with lack of chilling tempera- 
ture than is delay in opening of buds in southern California. The chilling, expressed as hours below $45^{\circ} \mathrm{F}$ during autumn and winter months in the deciduous fruit areas of northern California, is indicated in table 1 . These data are from thermograph records taken by the Division of Pomology since 1929. During this period, eight years were noted in which bud-drop was moderate to severe. The records have been tabulated to compare critical periods in the bud-drop years with corresponding periods in those years in which little or no bud-drop occurred. The highest and lowest values recorded in each period are also shown, to indicate the range in chilling among the bud-drop and non-bud-drop years.

At any one station, there was little or no difference between bud-drop and nonbud-drop years in the average amount of chilling during the September to November period. The average amount of chilling in the December, January, and February periods individually, and that accumulated for September through February, was greater in the non-bud-drop years in each district. December and January seem to be the most critical months. However, the high and low values recorded indicate that some bud-drop years had as much chilling or more than some of the years in which there was little or no bud-drop. This observation agrees with the earlier statement that a record of the number of hours below a base line, such as $45^{\circ}$ or $40^{\circ} \mathrm{F}$ is not always a dependable criterion of the adequacy of chilling. It does, however, suggest rather helpfully that a given season has or has not supplied enough chilling to prevent injurious bud-drop.

\section{Chilling Requirements of the Different Deciduous Orchard Species}

Species vary widely in their chilling requirements. Within species there are equally marked variations between varieties.

To publish an estimate of the chilling requirements for a species such as apple, with 1,440 hours at $45^{\circ} \mathrm{F}$ or lower; or peach, with 1,000 hours, is highly inadvisable because of the great variability among varieties. One might safely say that the average pear, peach, or plum variety does not require as much chilling as the average apple variety. Trees of some varieties, such as Bartlett pear, Mayflower peach, and Climax plum, however, require for satisfactory growth and

fruiting considerably more chilling than the average apple variety. Furthermore, among varieties of different species that require about the same amount of chilling to break the rest period completely, some may show in springs after very warm winters much greater abnormality in behavior of buds than others. Knowledge to be useful must concern behavior of varieties in specific situations.

Listed are different deciduous orchard species of fruits, nuts, and berries.

\section{FRUITS}

Apples. There is a very wide range in chilling requirements among apple varieties. Some seedling forms and local varieties grown around the Mediterranean, apparently of the same species as the apple, will grow and blossom well and fruit heavily after even considerably less chilling than is supplied by the warmest winters in southern California. They have little promise except possibly for breeding, however, for the fruit is small and has poor flavor.

Crabapple trees, of varieties such as Yellow Siberian, Red Siberian, and Transcendent, blossom and set fruit well, and Hyslop trees set fairly well after the warmest winters in southern California. These are hybrids between the true Si- 


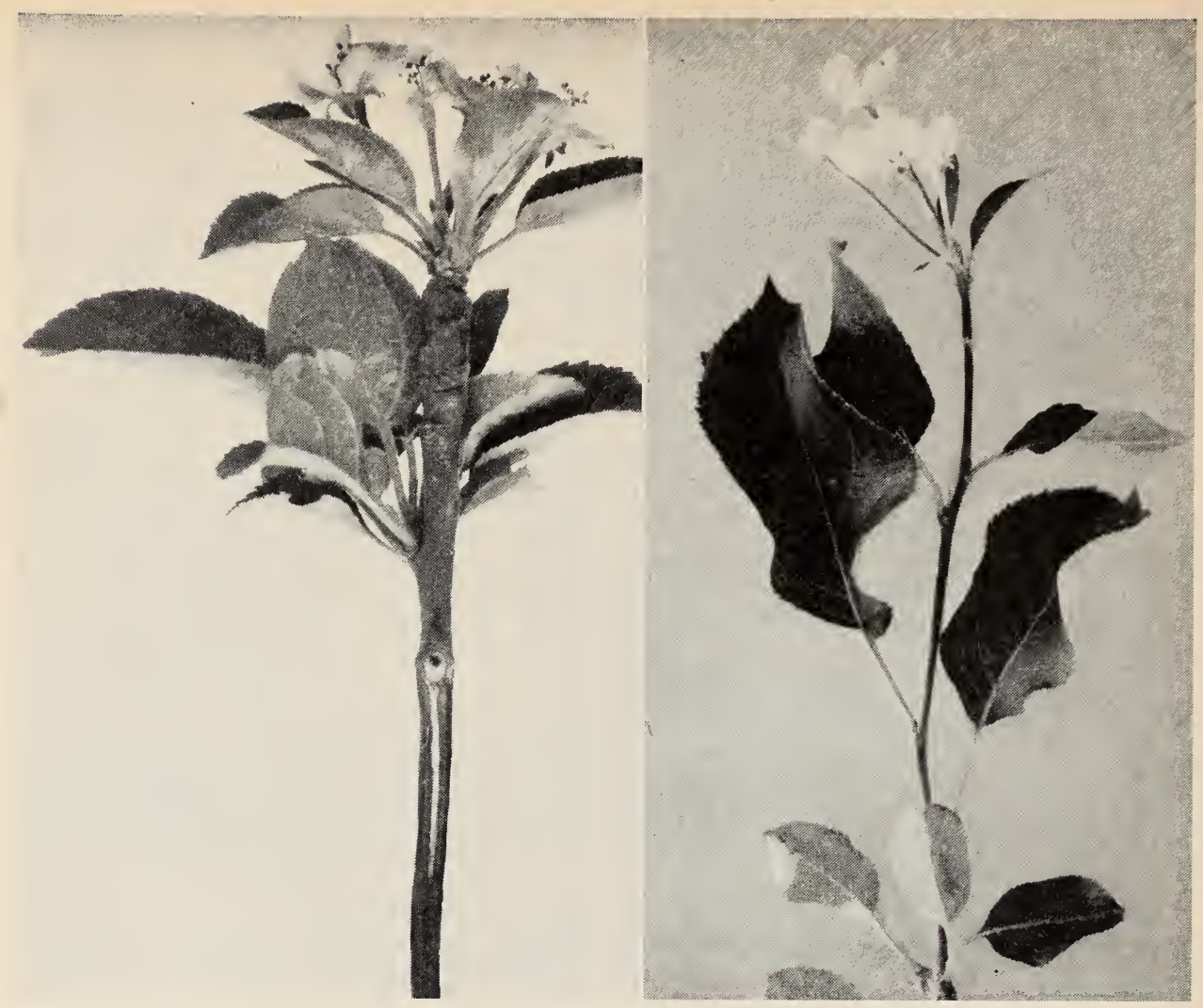

Fig. 8. Left: normal twig-terminal blossom cluster of Red Canada apple, just open on July 22, 1930, after a warm winter, above the winter fogs in Berkeley. Right: an abnormal cluster at the end of a rather long, leafy shoot.

berian crabs, Malus baccata, and common apples. A few varieties of apples, such as Wealthy, are from crosses between crabapples and some common apple, and tend to have fairly short chilling requirements, given by Malus baccata.

Trees of the varieties Hume, Wealthy, Early McIntosh, Winter Banana, White Pearmain, and possibly Wolf River, blossom and set fruit well after winters only a little cooler than most of those at low elevation in southern California, Hume better than the others after the warmest winters. Rhode Island Greening, Yellow Newtown, and Yellow Bellflower tend to require a little more chilling than White Pearmain, to cause the buds to open well; Delicious, Golden Delicious, Jonathan, Gravenstein, and Cox Orange, more than Yellow Newtown; Winesap.
Red June, and Red Astrachan, still more; McIntosh and Wagener still more; while Red Canada, Rome Beauty, Macoun, Twenty Ounce, and Northern Spy, among varieties that have been under observation in California, require for good growth and fruiting the most chilling. Blossoms like that at the left in figure 8, opening in July or later from buds that should have opened in the spring, are common as far north as central California. Such delayed blossoming and failure of any buds to grow from many twigs may be seen on trees of such varieties as Winesap in southern California; even buds of such varieties as Winter Banana and White Pearmain may be greatly delayed in opening.

Although the chilling requirement of McIntosh is nearly that of the longest of 
apple varieties, the chilling requirement of Hume, an open pollinated seedling of McIntosh, is the shortest, and that of Early McIntosh, a hybrid between McIntosh and Yellow Transparent, is as short as any of the others that have been observed in southern California. Melba is from another open pollinated seedling of McIntosh, with a chilling requirement about equal to that of Yellow Newtown or a little shorter. It fruits well in the parts of Berkeley with the warmest winters, hillsides above the winter fogs. In Los Angeles, however, it makes weaker growth than Winesap after the warmest winters, and has very few leaves; even those in the buds with the flower buds usually fail to open when the flower clusters open weakly, and little normal fruit is borne except in summers after the coldest winters.

About one thousand other seedlings are being or have been observed at Los Angeles. Most of these are crosses between some two of the three varieties Hume, Melba, and Early McIntosh. A hybrid between Melba and Early McIntosh has been named Beverly Hills. It bears as well as Early McIntosh or a little better after the warmest winters in Los Angeles, and its fruit is larger and has much better flavor-the most pleasing of summer apples observed in California. Other seedlings from these parents had short chilling requirements and bore good fruit but not as good as Beverly Hills. Hybrids between Melba and Hume tended to be larger trees, with shorter chilling requirements and larger fruits than hybrids between Melba and Early McIntosh; but the fruit of all in some years had an unpleasant bitterness; and none has been considered worthy of introduction. Hybrids between Early McIntosh and Hume also tend to be vigorous. Some have as short chilling requirements as Hume, and bear fruit that has less bitterness than that of any of the hybrids between Melba and Hume; one or more of such trees ripening fruit a little later than Beverly Hills may be considered worthy of introduction.

Spraying with DNO or DNC in February will nearly always cause earlier opening of buds of apple trees of any variety growing at low elevation in southern California. Figure 9 is of a Winter Banana tree, the right side sprayed, the left unsprayed. After the warmest winters at Riverside, both Winter Banana and White Pearmain trees showed a better response than Gravenstein. The response to spraying looked rather striking at the stage of development in figure 9, but later in spring the unsprayed trees of these varieties made about as much growth and yielded about as much as the sprayed ones. Gravenstein showed some response but least after the warmest winters when it was needed most, and the yield was not increased measurably. Spraying with DNO or DNC in oil did not cause Gravenstein trees to yield nearly as well after the warm winters as unsprayed Winter Banana or White Pearmain trees, nor as Gravenstein in northern California. Yet, following the exceptionally cool winter of 1948-49 these unsprayed Gravenstein trees yielded crops about as full as Winter Banana or White Pearmain. In Palestine, spraying with DNC in oil caused striking increase in yield of young trees of other varieties, such as Delicious and Rome Beauty. Possibly Delicious and Rome Beauty might have responded better than Gravenstein at Riverside. The evidence does not suggest that spraying to supplement the chilling in districts where the winters are as warm as those at low elevations in southern California can cause the trees to yield as well as they would if the chilling were adequate or more nearly so. Only trees with short chilling requirements can be expected to yield as much in southern California as trees in districts with more winter chilling temperature.

At elevations of about 5,000 feet in southern California, apple buds of such 


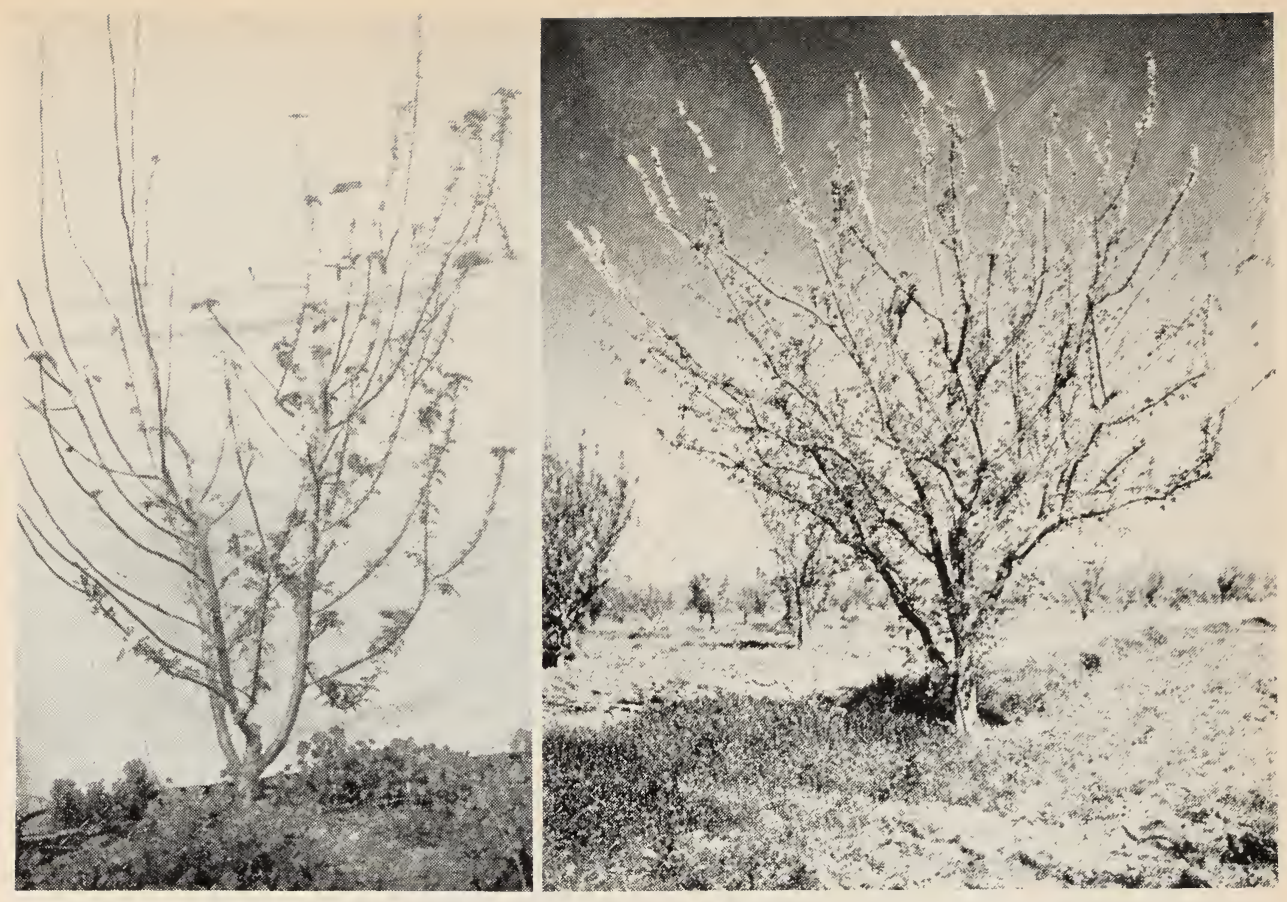

Left: Fig. 9. Winter Banana apple tree on April 1, 1937, showing results of spray of 2 per cent oil containing 3 per cent dinitro-o-cyclohexylphenol, given February 11, 1937, to right side only. Right: Fig. 10. Tilton apricot tree at Davis, March 30, 1930, after exceptionally warm winter. Blossoms barely open and leaf buds just breaking on long twigs in upper part of tree. Blossoms fallen and leaves nearly full grown on shorter, weaker twigs in lower part of tree.

varieties as Rome Beauty receive chilling enough to enable them to open and fruit to set well except after unusual winters. Since at such elevations there is likely to be a spring frost hazard, any delay-no matter how slight-in opening of the buds caused by inadequate chilling may be highly beneficial except after a rare winter that is warm enough to cause injurious delay, or dying of flower initials in the buds.

In South Africa, emphasis is placed on the use of rest-breaking sprays to induce uniform blossoming of the tree so that the calyx spray for codling moth will be more effective. In districts such as Sebastopol and Watsonville, where apples yield well but where some of the flowers are delayed in opening by rest influence still remaining in spring, possibly such spraying might shorten the blooming period after some of the warmest winters and make the calyx spray more effective. We do not have convincing evidence that the benefit would be great enough to repay the cost, even though the DN spray would be given in February only in years when December and January were exceptionally warm and sunny. In southern California, a DN spray may cause more of the buds to open at the beginning of the blossoming season but not nearly all. The blossoming period is long despite the spray.

Apricots. Leaf buds of most apricot varieties and fruit buds remaining on the tree do not require as much chilling to enable them to open by the first of March as do buds in most of the well-known varieties of apples, pears, peaches, plums, and cherries. The buds grow at rather low temperature, however (apparently even lower than the temperature at which almonds begin to grow), and so they are likely to begin the process of opening before their rest periods are completely 
broken, even in central California. Buds on long twigs, such as those in the top of the Tilton tree in figure 10, will have more rest influence left than buds on lower, weaker twigs. Leaves were nearly full grown and the blossoms had fallen from the lower, weaker twigs of this tree by March 30, 1930, when blossoms were opening and leaf buds barely breaking on the long ones in the top. Figure 11 shows the variation in size of fruits on a Royal apricot tree on that date at Winters. If the rest period had been completely broken before the weather began to be warm enough for growth, buds on a tree would have opened more nearly all at the same time, and considerably earlier, as early as almond buds open or a little earlier. The chilling requirement of such apricot varieties as Royal is only moderately long, however. After the warmest winters even in southern California, leaf buds open well enough to produce good growth on all branches.

The greatest losses in apricot orchards caused by warm winters are from shedding of opening flowers and of buds before they begin to open. Unlike the mixed buds of apples and pears, which may open into a leafy shoot after some or all the flowers have died during warm winters, flower buds of the apricot, peach, and plum have only flowers; if the flower initials die, the bud falls. On apricot trees the number of flower initials that die before the buds begin to open tends to be much greater than the number of flowers that fall after they are partially open. In figure 12 are two apricot shoots on each of which all the flower buds except one have died and are falling. The flower initials may be dead long before the buds fall. After some winters even in central California the shedding of apricot buds causes considerable losses. After the same winters in these central California districts, trees of peach and pear varieties, with longer chilling requirements than apricots, may not be injuriously delayed in blossoming or beginning of shoot growth.

In central and northern California, no time has been found at which spraying with DNO and oil will reduce the shedding of apricot flower buds, although it may hasten opening of leaf buds in
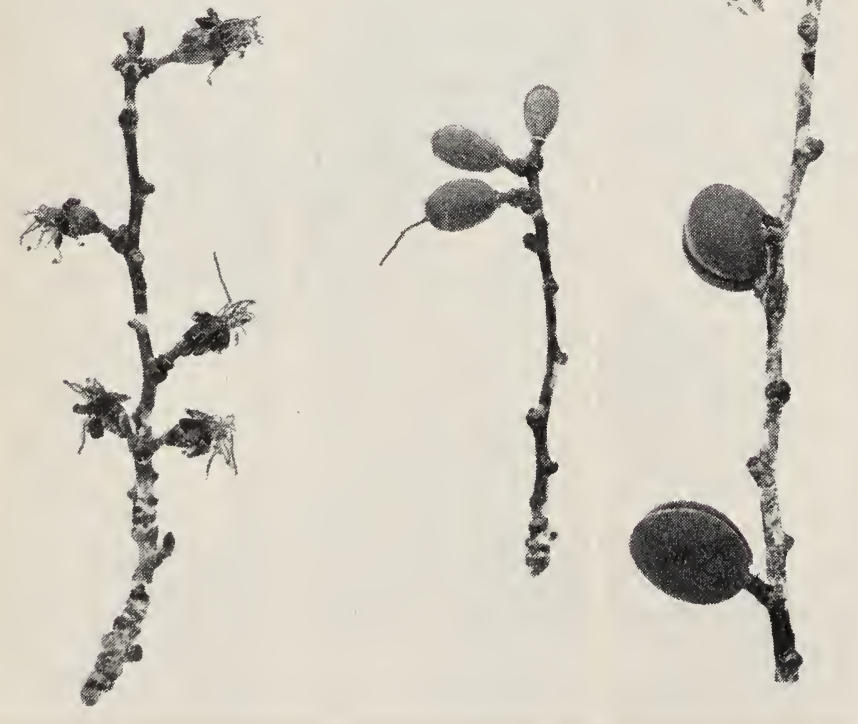

Fig. 11. Twigs taken from Royal apricot trees on March 30, 1930, at Winters, in northern California, showing variation in size of fruit. This variation was caused by greater delay in opening of some buds than of others after a warm winter. 


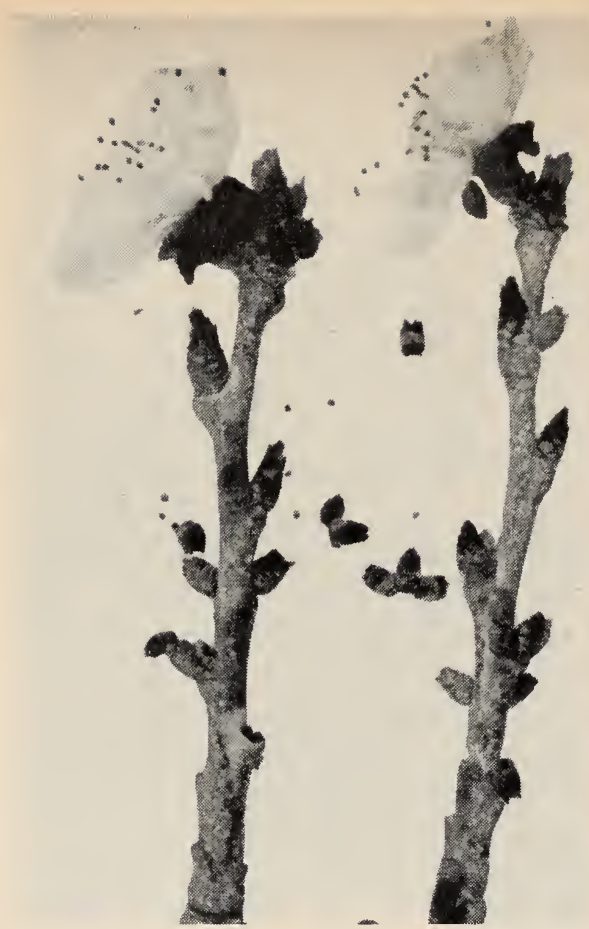

Fig. 12. The shedding of apricot fruit buds after a warm winter. Sometimes many of the blossoms that are delayed in opening after such winters also fall without setting fruit.

spring. Apparently death of the flower initials is caused by warm weather after leaf fall but while they are still in the rest period, and in these parts of California, apparently warm periods in December or January may cause death of apricot flower initials; the total amount of chilling by spring in such winters may be enough to cause leaf buds and uninjured flower buds to open normally. Trees that shed their leaves early in autumn because of nitrogen deficiency, poor, gravelly soil, or water deficiency in late summer, are more likely to shed their flower buds.

In southern California spraying with DNO and oil in late January may increase the yield of Newcastle trees after some of the very warmest winters and may increase the yield of Royal trees after slightly cooler winters. In some years it may not increase the yield of fruit of good market size but may only increase the thinning cost, or the breaking of branches. Tilton trees must be sprayed a little later-about February 15; and after the warmest southern California winters, Tilton trees do not respond measurably to the spray. Fairly good results are shown only after winters a little cooler than the average. At Riverside, Royal trees that had been sprayed for five years with DNO were smaller than unsprayed trees alternating with them in the row. The evidence is not entirely convincing as to whether this is accidental or due to a toxic effect that reduces growth of the trees without visible injury to the leaves.

Blenheim and Royal are the varieties largely grown in California, perhaps in part because they are less likely to shed their flower buds than other varieties. Such varieties as Moorpark, Hemskirke, large Early Montgamet, and others that tend to bear good crops after the colder winters of Utah and Washington, shed their buds and bear only very light crops in California after many winters, even as far north as Davis. Newcastle trees tend to bear better than Royal after warm winters, and Reeves trees are reported to do so and to bear larger fruits than Newcastle trees. Trees of these two varieties will bear acceptable crops without the DNO spray after nearly all winters, even along the coast in southern California. Tilton trees more than Royal usually shed their buds after warm winters; and in southern California they may bear very little after most winters. The fruiting of apricot orchards in California will be made more dependable only by obtaining good varieties that do not shed their flower buds after warm winters. However, keeping the trees of such varieties as Royal so vigorous that they hold their leaves rather late will tend to reduce shedding. This can be done by good soil management and adequate pruning.

Cherries, Sweet. After moderately warm winters, like those in the Sacramento Valley, buds of most varieties of sweet cherries, Prunus avium, are delayed a little more than buds of common 
peach varieties, such as Elberta and Phillips Cling. For example, in New York after its long winters, trees of sweetcherry varieties blossom as early as peach trees or a little earlier; while at Davis, with winters a little too short to break the rest period completely, trees of sweetcherry varieties tend to blossom later than trees of most peach varieties.

After the warmest winters in southern California, sweet-cherry buds are delayed greatly but eventually tend to open better than peach buds. Apparently, after there has been some winter chilling, longcontinued dormancy tends to serve as a substitute for the remaining part of the chilling requirement better with sweet cherries than with peaches. Sweet-cherry trees seem to be less likely to shed their buds during warm winters than peach or apricot trees. Yet, except at elevations of about 1,500 feet or more in southern California, the trees do not set fruit as well as do peach trees of varieties such as Elberta; and spraying with DNO causes little or no improvement.

The delay in blossoming from warm winters is greater for some varieties, such as Bing, Lambert, Napoleon (Royal Ann), and Yellow Spanish, than for others, such as Republican (Black Republican), Black Tartarian, Burbank, and Chapman. This difference in chilling requirement will sometimes cause trees of a variety to blossom too late to receive pollen from trees of another variety depended upon to supply pollen for them. After such winters, it is not always possible to determine whether the failure of trees to set fruit is due to lack of pollen or to shedding of open flowers caused by delay in opening.

Cherries, Sour. The varieties of sour cherries, Prunus cerasus, that have been tried where the winters are warmest in southern California have longer chilling requirements than most sweet-cherry varieties. They may be delayed, somewhat injuriously, in years when trees of most peach varieties and sweet-cherry varieties, and some apple varieties, start well enough. Figure 4, page 7 , shows strikingly the delay in starting that may result from insufficient chilling.

The fruit buds of sour cherries are not so likely to be shed as apricot or peach buds, and, on English Morello at least, a tree badly delayed in starting may eventually have a full blossom. Sometimes enough of these blossoms set for a fair yield of late fruit. In other years, however, such late blossoms may set very few fruits, or none. It rarely sets fruit in warm, coastal districts of southern California. Montmorency and Early Richmond trees seem to be injured more by very warm winters than English Morello or Empress Eugenie trees.

Cherries, China. The Chinese cherry, Prunus pseudocerasus, has a very short chilling requirement and will open its buds early after the warmest winters in Berkeley.

Figs. After the first two or three years in the orchard, fig trees tend to cease shoot growth about as early as other deciduous fruit trees. The buds are then prevented from growing by what seems to be a rest period, such as that of other deciduous species. At least they show slight delay in starting after the warmest winters in southern California and a slightly earlier starting on trees sprayed with DNO. Trees will start growth early enough, however, and will fruit well after winters considerably warmer than any in southern California. Brunswick trees are among the most resistant of fig trees to cold and might be expected to have the greatest chilling requirement. Yet, a tree apparently of this variety was seen at low elevation in Honduras, where there is no chilling temperature, fruiting more heavily in 1947 than trees of that variety tend to fruit in California.

During the first two or three years in the orchard the trees tend to grow late and still be succulent when danger of autumn frosts begins, yet they start growth satisfactorily in the following 
spring. In other words, whatever the chemical influence may be that causes the rest period (prevents buds from growing when environmental conditions and their positions on the shoots are favorable for growth), it must either be weaker in certain kinds, such as the fig and the persimmon, or the changes that remove it from these buds must be more rapid than in such varieties as Winesap or McIntosh apples that without chilling will be many months in starting.

\section{Grapes, Vinifera (Old World).} Vines of at least some varieties of vinifera grapes, Vitis vinifera, require some chilling. For example, in some of the warmest parts of southern California, buds of Thompson Seedless (Sultanina) have been observed to start earlier and more uniformly if the vines were in shade, such as that of an evergreen hedge, during December and January. On the other hand, vines of the varieties observed seem to start much better than apple trees or peach trees, of the common varieties, after the warmest winters at Ontario and some other areas in southern California.

Grapes, Labrusca (Slipskin, American). The labrusca species, Vitis labrusca, is native to the rather cold winters from north Georgia to the New England states, yet it has an exceedingly short chilling requirement, so short in some varieties that it can be replaced as early as autumn by such influences as pruning wounds near the buds. In parts of Berkeley above the winter fogs, where the winters are warm enough for at least slow growth nearly all the time, shoot growth will start in the middle of winter on some varieties, especially the labrusca-vinifera hybrids Catawba, Herbert, Massasoit, and Barry. The flowers on such shoots usually do not set fruit. Even Concord, Worden, Diamond, and Niagara vines may start growth too early in some Berkeley winters to bear good flowers. Pure vinifera varieties observed there, such as Muscat Hamburg and Chasselas Doré, remain dormant through these winters and start growth satisfactorily in spring.

Pierce, Isabella, and Ione are labrusca varieties that have long been known to hold their buds dormant until spring and to bear well after the warm winters in coastal sections of California. The excellent new varieties from the New York Experiment Station, Golden Muscat and Urbana, fruit well in such sections.

In the Sacramento, San Joaquin, and other valleys, where most of the winters are cold enough to prevent growth until spring, such labrusca-vinifera hybrids as Barry and Catawba set somewhat better crops than in sections with winters as warm as those in Berkeley.

Grapes, Other. Two varieties, Delaware and Berckmans, from crosses among the American species, Vitis vulpina, $V$. labrusca, and $V$. aestivalis var. bourquiniana, remain dormant during Berkeley winters well enough, and Berckmans fruits rather well.

While some species of grapes observed have rather slight chilling requirements, it is interesting to note that one Chinese species grown as an ornamental, Vitis Davidi, has a longer chilling requirement than even Northern Spy apple. In the spring of 1936 in the Berkeley hills the first few buds were just bursting by April 29, while at Sebastopol, where the winters are colder, shoots were nearly 2 feet long.

Nectarines. The range of chilling requirements in the older nectarine varieties is much like that among common peach varieties, that of Stanwick nectarine about like Mayflower peach, that of most other varieties about like Elberta peach, that of Gold Mine nectarine about like Sims, Early Imperial, or Socala peach. A new variety, Pioneer, is said to have a chilling requirement so short that it fruits dependably after the warmest winters in southern California.

Peaches. There are several groups of peach varieties with different chilling requirements. The largest, which includes 


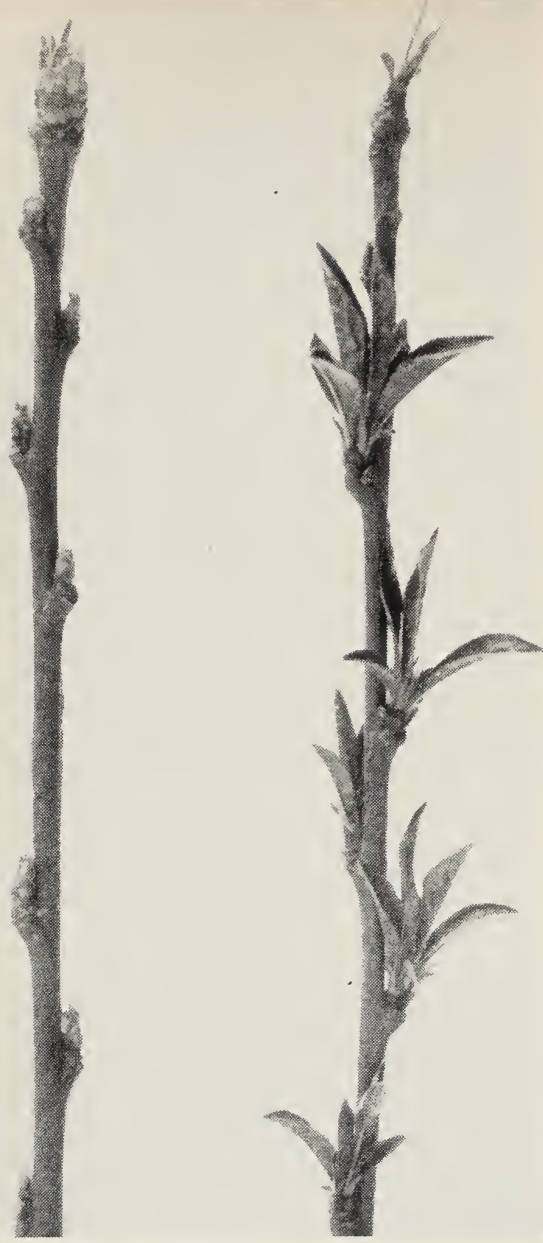

Fig. 13. Twigs of Lovell peach beginning to grow in spring after a winter too warm to break the rest period completely. Left: a one-year-old twig. Right: a two-year-old twig from the same tree.

most of the old, well-known peach varieties, will be called common peaches in this paper. Most of these varieties do not require as much chilling to break their rest periods completely as the average variety of apples; they will set full crops after winters warm enough to reduce the crop on trees of many apple varieties. Yet after still warmer winters, the crop on trees of such varieties as Elberta may be reduced more than the crop of an apple variety with a medium chilling requirement. Among these common peach varieties are a few, such as Mayflower, with very long chilling requirements and some, such as Sims, Early Imperial, Socala, and Hiley, with chilling requirements so short that they bear full crops after some winters at low elevation in southern California. When the winters are especially warm, leaf buds on many twigs of common peach varieties do not grow in the first year after they are formed, and in their second winter have shorter chilling requirements than in their first. If the second winter also is a warm one they will open earlier than buds on twigs that are only a year old, as shown in figure 13.

Another group is known as Spanish or Indian peaches, usually grown as seedlings, from strains apparently brought to American southern states by the Spanish. Some of these trees have considerably shorter chilling requirements than trees of most common peach varieties, as figure 14 shows.

Two varieties from south China have become the parents of varieties suitable for growing even farther south than southern California. One of theseHoney-produces an oblong, beaked fruit that is very sweet with little or no acid. A number of its seedlings that produce such mild, sweet fruit have been propagated, especially in Florida. The other variety, Peen-to, is more strikingly different from common peaches. The fruits are small, with their depressed blossom end suggesting the name "saucer peaches," which they are sometimes called. The flavor is sweet with a tinge of bitterness, not very pleasant to the taste. Seedlings of these two varieties and Spanish peaches have been crossed with the best of the common peach varieties. Two of these introduced in 1933 as Babcock and C. O. Smith have been planted in southern California, Babcock rather extensively. The fruits tend to be too small, unless an expensive amount of thinning is done, and their sweetness without acidity or other flavors characteristic of common peaches is not liked by some people. Recently, breeders have 
been so successful that a rather large number of excellent varieties are now available, with flavor as good as that of such varieties as Elberta and J. H. Hale. Fortunately they vary both in chilling requirement and in flavor. In districts away from the coast, those varieties will be best that have enough chilling requirement to delay blossoming in spring and reduce the frost hazard. In coastal districts, varieties with shorter chilling requirements will be wanted, and varieties with less of the acidity and bitterness that so enrich the flavor of Elberta and J. H. Hale in interior districts.

Varieties well suited to all parts of southern California and ripening in different parts of the summer will almost certainly be found among such varieties as Bonita, Rubidoux, Curlew, Flamingo, Golden Blush, Hermosa, Meadow Lark, Redwing, Robin, Sunglow, Weldon, and the considerable number of seedlings that breeders will name soon. Some of them are now finding a good place in California markets.

Peach trees with only part of the chilling requirement satisfied will respond to
DNO or DNC sprays, but not as well as plum or apricot trees. Varieties such as Mayflower and Alexander with unusually long chilling requirements will make very little response after the warmest winters at low elevations in southern California and bear very little fruit, but will respond fairly well after the coolest winters. Varieties such as Elberta, with medium chilling requirement, may not need the spray after the coolest winters and respond fairly well to it after warmer ones.

In the San Joaquin, Sacramento, and Santa Clara valleys, and in foothill districts above them, the small delay in blossoming from slightly inadequate chilling reduces the frost hazard and makes the peach crop more dependable than in districts with longer, colder winters. In some years, however, in warm parts of these valleys, trees of Mayflower and a few other unimportant varieties with exceptionally long chilling requirements may shed too many of their flower buds or opening flowers for a full crop to be borne. Even the crop of Phillips Cling is rarely reduced by such shedding of buds. After warm winters of southern

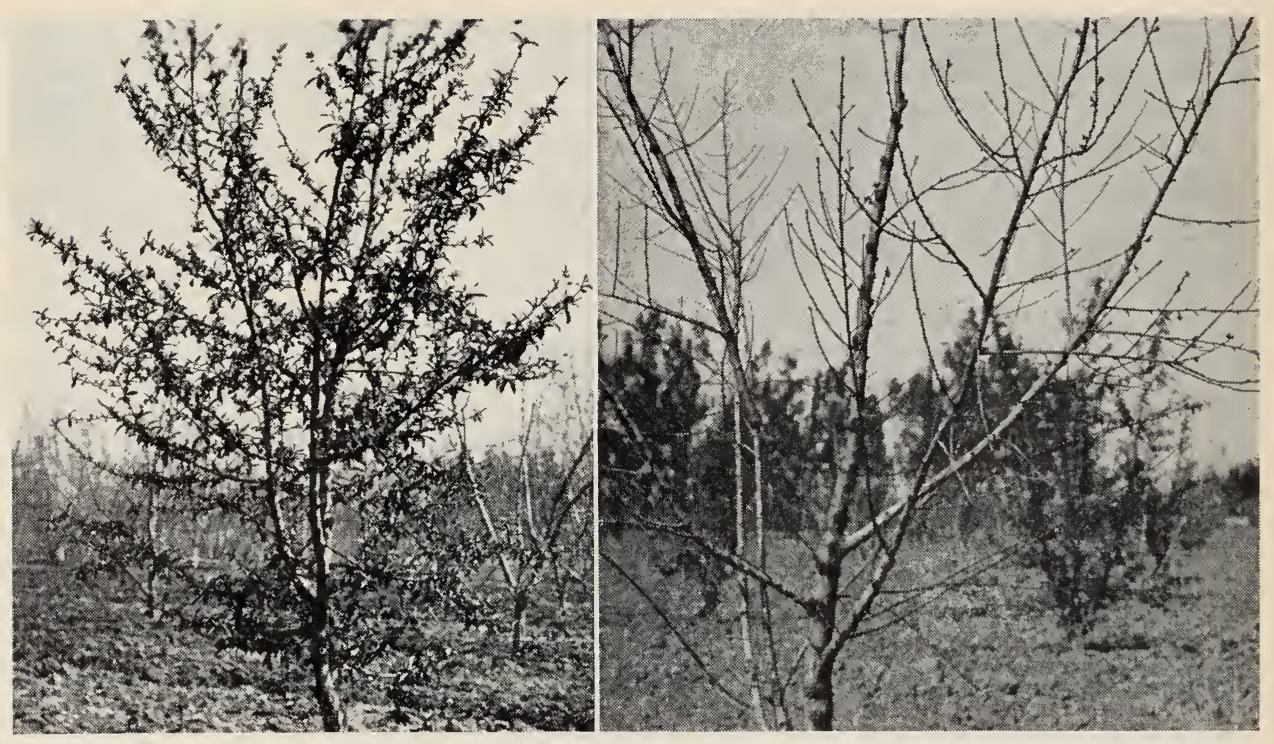

Fig. 14. Amount of growth made on trees of different varieties of peaches by April 13, 1934, after an especially warm winter at Ontario. Left: a tree from a cross made by Weldon between Sims and a tree of the Spanish type. Right: a tree of Peak, a common peach variety. 


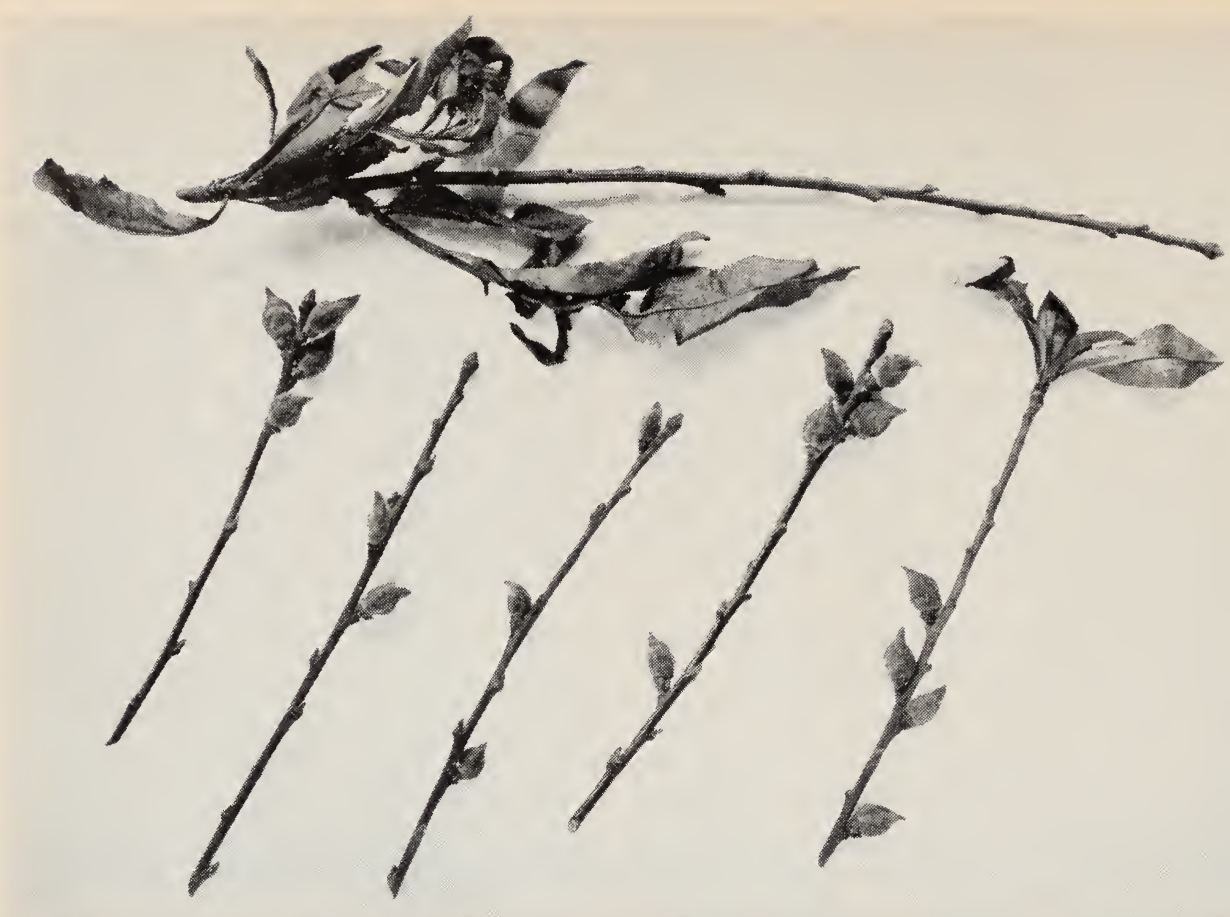

Fig. 15. Phillips Cling peach branches taken at Ontario, June 15, 1931. On all but one branch the terminal bud failed to grow; and all but two lateral leaf buds also failed. Some of the flowers set fruit, but most apparently were not pollinated since they are shriveled, ready to fall.

California, many of the flowers of both Phillips Cling and J. H. Hale trees may set fruits that remain small and woody like those in figure 15.

Pears. Most of the pear orchards are in the valleys and foothills of central and northern California, where crops are rarely reduced much by lack of winter chilling. Possibly a DNO or DNC spray in February after an especially warm December and January might, by shortening the blossoming period, make the calyx spray for codling moth more effective and reduce the danger of fire blight spread. The longer the blossoming period the greater the danger that some part of it will be in weather favorable to the spread of fire blight, but the spray would be followed many times by no clear evidence of benefit. And it might, under some conditions, actually make the blossoming period longer. Buds on the north side of each tree, partially shaded during the winter, might be the only ones that have had chilling enough to enable them to respond to the spray. Their opening might be hastened and the spray might not influence the buds that start latest, those that have been warmest during sunny winter days.

A considerable number of pear varieties have been observed in Berkeley, on a hillside above the winter fogs, where Decembers and Januarys are nearly as warm as those in Riverside, and on low ground where fogs keep the bud temperature considerably lower but not as low as that in most pear-growing districts. On the hillside in Berkeley, the order of blossoming in spring is usually as follows: P. Barry, Forelle, Flemish Beauty, Anjou, Clairgeau, Louise, Dana Hovey, Seckel, Louis Pasteur, Winter Nelis, Duhamel, Comice, Superfine, La Favorite, Bosc, Hardy, Elizabeth, Packham Choice, Marguerite Marillat, Frederick Clapp, 
Bartlett, and Gorham. Order of blossoming may be partly due to the cool springs in Berkeley. Some varieties such as P. Barry and Forelle will start growth at lower temperature than others. The order there is due largely, however, to the amount of rest influence left to retard opening of the buds. That order is very different from the order in a climate like that of New York, where no rest influence is left to retard bud opening in spring. In such a climate, Bartlett blossoms relatively early and Winter Nelis late. In California, even at Davis where the amount of winter chilling is considerably greater than at Berkeley, Winter Nelis blossoms earlier than Bartlett, as figure 16 shows, sometimes considerably earlier if the winter is warmer.

Most pear varieties blossoming in Berkeley earlier than Packham Choice have a little less chilling requirement than apple varieties except a few, such as Hume, Beverly Hills, Early McIntosh, Winter Banana, and White Pearmain; but Bartlett has a greater chilling requirement than medium apple varieties, such as Golden Delicious or even Winesap; and Gorham has still greater so that it will hardly grow at all in Berkeley and will not grow well enough in some good Bartlett districts in California.
Bartlett's long chilling requirement tends to make it unsuitable for growing in the orchard or the dooryard at low elevations in southern California and at coastal positions with the warmest, sunniest winters as far north as central California, but makes it an exceptionally good variety for growing in other districts. The rest influence remaining in spring delays its blossoming somewhat; this reduces the frost hazard and tends to cause the flowers to be open for pollination in better weather. In sunny foothill districts, some flower initials may die in the buds during especially warm winters, but even in these districts such losses are small compared with the frost damage that would result if blossoming were not delayed by rest influence.

Persimmons. Nearly all varieties of oriental persimmons, Diospyros kaki, are especially well suited to a climate like that of southern California, with winters too warm for normal spring behavior of trees of most varieties of other deciduous fruits, but with possible killing frosts in autumn, winter, or spring. Persimmon buds are usually in the rest period by late summer so that even severe pruning of the trees will not cause them to grow. They are almost certain to be dormant in autumn and early winter and therefore
Fig. 16. Left: Winter Nelis pear tree almost in full leaf, blossoms fallen. Right: Bartlett tree with buds just opening, at Davis in spring of 1935, after an especially warm winter.

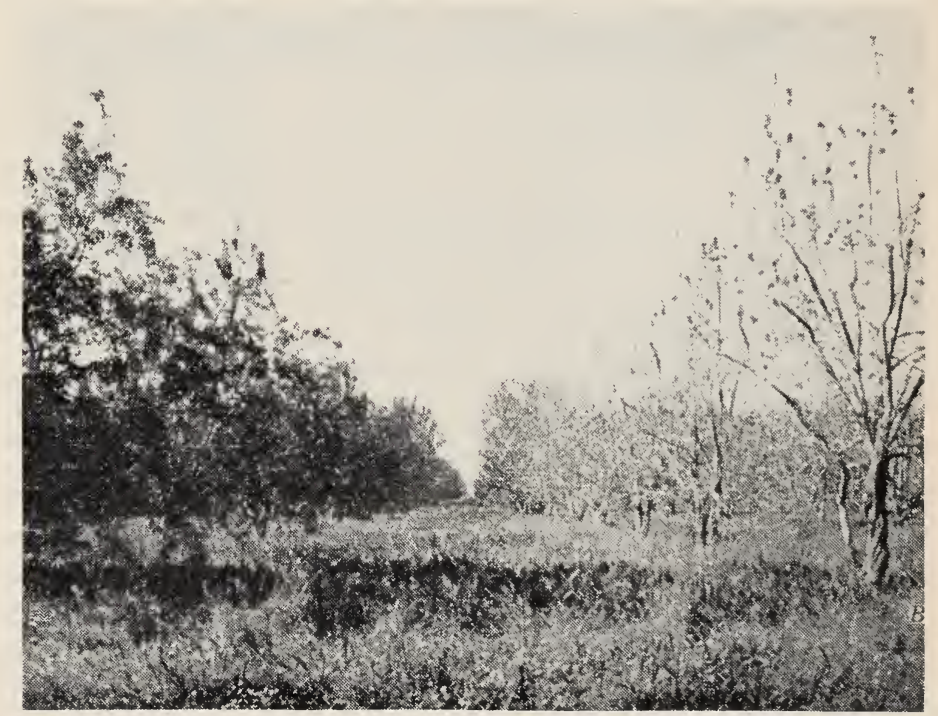

[29] 
resistant to lower temperature than any to be expected in California below an elevation of 3,000 feet. Yet after leaf fall the rest period is so easily broken that in all but a few unimportant varieties the buds open normally, all together, after the warmest winters in southern California. Even in colder districts, the flowers are borne on the new shoots so late in spring that they are in little danger from spring frosts. Apparently the oriental persimmon would be an ideal orchard species for most fruit-growing districts of California if people would buy the fruit.

Trees of the American persimmon, Diospyros virginiana, tend to have a longer chilling requirement. Of three named varieties planted in the University orchard in Los Angeles, the buds of Early Golden and Ruby are delayed a little in starting after warm winters but fruit rather well, while Miller buds are delayed too much for satisfactory growth in that area.

Plums, American. Buds of one American species, Prunus americana, have longer chilling requirements than buds of most of the common deciduous fruits. This is true of all the varieties in the University planting-Terry, Hawkeye, Wyant, and Hammer. Even at Davis, they open later than buds of most other orchard species except after the coldest winters. In hills above the winter fogs in Berkeley the delay is much greater. An abnormally small percentage of the buds ever open.

Other American species of plums, such as Prunus hortulana and $P$. munsoniana, have long chilling requirements but not as long as $P$. americana or $P$. nigra.

Plums, Damson. There are a number of varieties of plums in the Damson group. Trees of the leading variety, Shropshire, have very long chilling requirements, so long that they rarely start growth, and blossom normally in the hills above the winter fogs in Berkeley. A variety sold as Damson by a southern California nurseryman may not belong in that group, but its fruit is as good as Shropshire or better for any use that is made of that variety and is larger and less expensive to grow. The tree is better than Shropshire and sets good crops after the warmest winters in southern California.

Plums and Prunes, Domestica. These varieties are in the species Prunus domestica, which came to us through Europe from their native home in western Asia. They are sometimes called European plums. Not many of them are grown in southern California, where their chilling requirements can be observed carefully. Some of them, such as President and Diamond, do not fruit any better than Bartlett pear, if as well, after the warmest winters there. French prune (Agen) is only a little better, but it responds to a February spray with DNO. Some varieties, such as Tragedy and Sugar, will blossom and set fruit well after any but the warmest winters in southern California. All these varieties and others-Jefferson, Washington, Reine Claude, and Yellow Egg-tend to fruit well after the warmest winters in central and northern California except on hillsides above the winter fogs in some coastal positions. But after such winters they may blossom a little earlier if they have been sprayed with oil in January. Probably the DNO or DNC spray would be a little more effective.

Plums, Oriental (Japanese). Among varieties of oriental plums, Prunus salicina, Mariposa and Inca have the shortest chilling requirements of any that have been under observation at Riverside. They are completely or almost completely self-unfruitful and do not seem able to pollinize each other. Except near the coast, Santa Rosa blossoms almost as well as Mariposa and Inca after the warmest winters in southern California, probably always near enough to these other two to pollinize them fairly well. These three varieties are being used by one large nursery in breeding plums for southern California. Since they are among the best 
of oriental plums in flavor, there is strong promise that, before many years, an excellent group of varieties with short chilling requirements will be available. Methley buds open only a little later than buds of Santa Rosa, Mariposa, and Inca after warm winters, followed rather closely by Becky Smith and perhaps Satsuma.

Wickson and Kelsey have longer chilling requirements. These varieties are selfunfruitful, and if trees of one of them are dependent for pollen on trees of a variety such as Santa Rosa with a short chilling requirement, they may fail to set much fruit in the spring after a warm winter. Very few flowers may open before all flowers of the variety with the shorter chilling requirement have ceased to shed pollen. Apex, Duarte, Gaviota, and Beauty trees have still longer chilling requirements, and Climax even longer. Trees of nearly all varieties of apples, pears, and peaches fruit better than Climax plum trees after the warmest winters in southern California.

Trees of Wickson and Kelsey, and probably of other varieties with intermediate chilling requirements, respond rather strikingly to spraying with DNO in late January. Trees of Beauty respond well after moderately cool winters but not after the warmest. Climax trees respond rather well only after the coolest winters and must be sprayed late in February to cause effective response.

Santa Rosa and most or all of these varieties with longer chilling requirements may shed their buds rather badly after some warm winters in southern California and after some especially warm winters in foothill districts above the valley fogs, even in central California.

Quinces. Buds of the common quince, Cydonia oblonga, do not require much chilling and will open, nearly all together, where the winters are as warm as those in Los Angeles or warmer. The quince is the last of the fruit trees to blossom in districts where the winters are so long that the rest period of all kinds is completely broken before warm spring weather begins. This is partly because the flower is at the end of a leafy shoot that must have time to develop before the flower can open. In California, with its mild winters, the quince buds are not delayed by much rest influence and, therefore, begin growth so early that the flowers open before those of common apple varieties or Bartlett pear, or most cherry varieties. After the still warmer winters of southern California they open before buds of most varieties of peaches or plums.

\section{NUTS}

Almonds. At least one variety of almond-Harriott-begins to blossom soon after leaf fall in the warm winters of southern California and may be in full blossom by midwinter. In other words, it has only a little rest influence left after leaf fall. Other varieties that have been observed have chilling requirement enough to delay their blossoming a little in southern California, to make their flowers a little later than those of the same variety in coastal districts of central California, where the rest period is broken by the amount of chilling before the middle of January. From central California northward the time of blossoming of al- mond trees is determined entirely by heat required for bud growth; difference in time of blossoming and leafing of trees of different varieties is due to difference in temperature required for growth, unless December and January are very much warmer than normal. The great frost hazard to the almond is due to its small chilling need and the rather low temperature at which its buds will grow.

Chestnuts. Varieties, seedlings, or hybrids of four species of chestnuts are being tried in California. These are Castanea mollissima, the Chinese chestnut; C. dentata, the American chestnut; $C$. sativa, the European, sometimes called 
the Italian or the Spanish chestnut; and C. crenata, the Japanese chestnut. After the warmest winters in Berkeley, Chinese chestnut trees start early, all their buds at about the same time, as if their chilling requirements had been fully satisfied. This is true also of Boone and Colossal, probably hybrids between American and Japanese chestnuts. On the other hand,
Quercy, a variety of the European chestnut; Progress and Rochester, AmericanEuropean hybrids; and the ornamental variety, Fountain, show some delay and unevenness in opening of the buds, as if somewhat more chilling would be required for unhindered opening. Enough buds grow for satisfactory development of the trees, however. In Orange County,
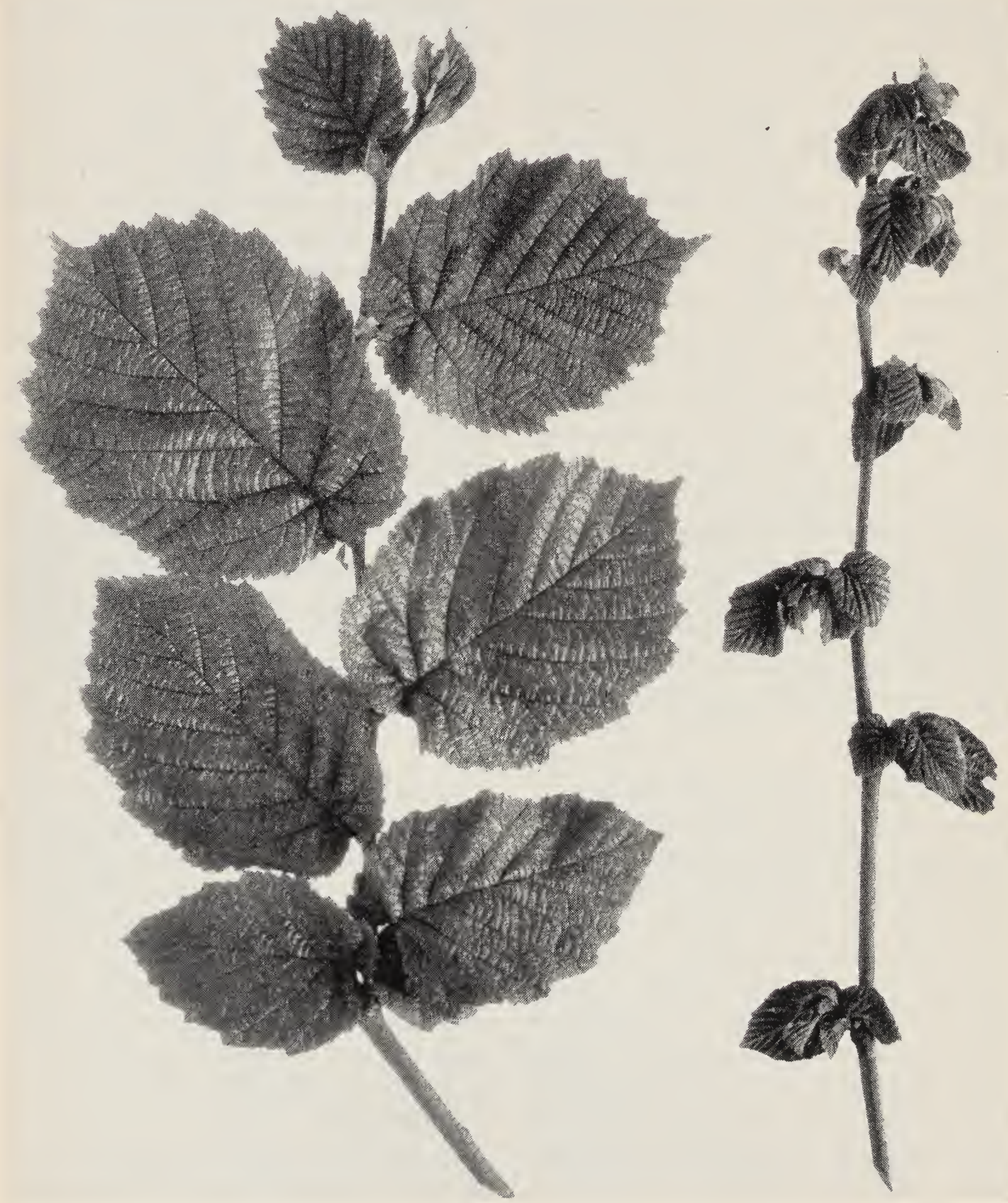

Fig. 17. Growth from filbert buds, Macrocarpa variety, at Berkeley, by April 17, 1936. Left: shoot from a bud on a scion that had been chilled two months at $32^{\circ} \mathrm{F}$ before it was set. Right: growth just starting from buds exposed to the warm winter. 
some unnamed old chestnut trees, probably European, showed injurious delay in starting of the buds after one of the warmest winters. Our observations suggest that some chestnut varieties may require more chilling for best development of the trees than the warmest winters in southern California give, but not as much as Franquette and Eureka walnuts.

Filberts, or Hazelnuts. In Berkeley, on trees of nearly all filbert varieties observed, there is some delay in starting of the leaf buds after winters warmer than the average. Barcelona shows less delay than any other except Fertile de Coutard; yet Barcelona trees held in cold storage at $32^{\circ} \mathrm{F}$ for 2 months and then put in the orchards with the others, had leaves $13 / 4$ inches across when none was more than $1 / 4$ inch across on trees remaining in the orchard. Trees of Du Chilly, Nottingham, Prolific Cobb, Geant de Halle, Cosford, Emperor, Gassoway, and Macrocarpa (fig. 17) are delayed as much as Delicious apple trees or more, in springs after warm Berkeley winters. Eventually, however, enough buds grow to make the tree as a whole show much better development than Delicious apple trees after those winters. Barcelona and some varieties with longer chilling requirements make good growth, although starting late in spring, even after the warmest winters in southern California. Fruiting, however, has not generally been satisfactory.

On most varieties the opening of pistillate (female) flowers is delayed and straggling in Berkeley winters if there is not enough chilling. Pistillate flowers on Barcelona trees held for 2 months at $32^{\circ}$ F opened earlier and more nearly all together than flowers on trees left in the orchard. On the other hand, development of catkins and shedding of pollen are not delayed so much, are sometimes even hastened, by warm winters. For these reasons, it may require several varieties shedding pollen through a long period, some shedding it as late as March, to give satisfactory pollination, where the win- ters are as warm as some of those in Berkeley. In the Sacramento Valley and its foothills there seems always to be chilling enough for early starting of growth. In this area there is no evidence that delay in the opening of pistillate flowers complicates the pollination problem. Shedding of the catkins in autumn seems to be the chief cause of failure to fruit.

Walnuts. Varieties of Persian walnuts, Juglans regia, often called English walnuts, grown in California are mainly from three strains: 1) the Santa Barbara soft shell, of which Placentia is the best known representative, Ehrhardt, Chase, Wasson, and Pride of Ventura being other representatives, all grown mainly in southern California; 2) French varieties, Franquette and Mayette, and seedlings from them, such as Concord and Payne, all but Payne grown mainly in northern California; and 3) Eureka and Blackmer, from trees of Persian walnuts that were here before the introduction of the Santa Barbara soft shell and the French varieties, these also grown mainly in northern California. A considerable number of trees of Eureka and more of Payne have been planted in southern California. Enough trees also of each of the other northern California varieties have been planted in southern California to give information about how they behave after warm winters.

All the northern California varieties have rather long chilling requirements, Franquette and Mayette the longest (as long as that of an average variety of apples, or longer), Payne the shortest, Concord a little longer than Eureka and Blackmer. There seems never to be injurious delay of the buds of these varieties in northern California, however, unless possibly some of the dying back of long shoots on young trees is due to chilling insufficient for the buds to start. More chilling is required by buds toward the ends of long shoots to start normally in spring than by buds on short, early maturing shoots. 


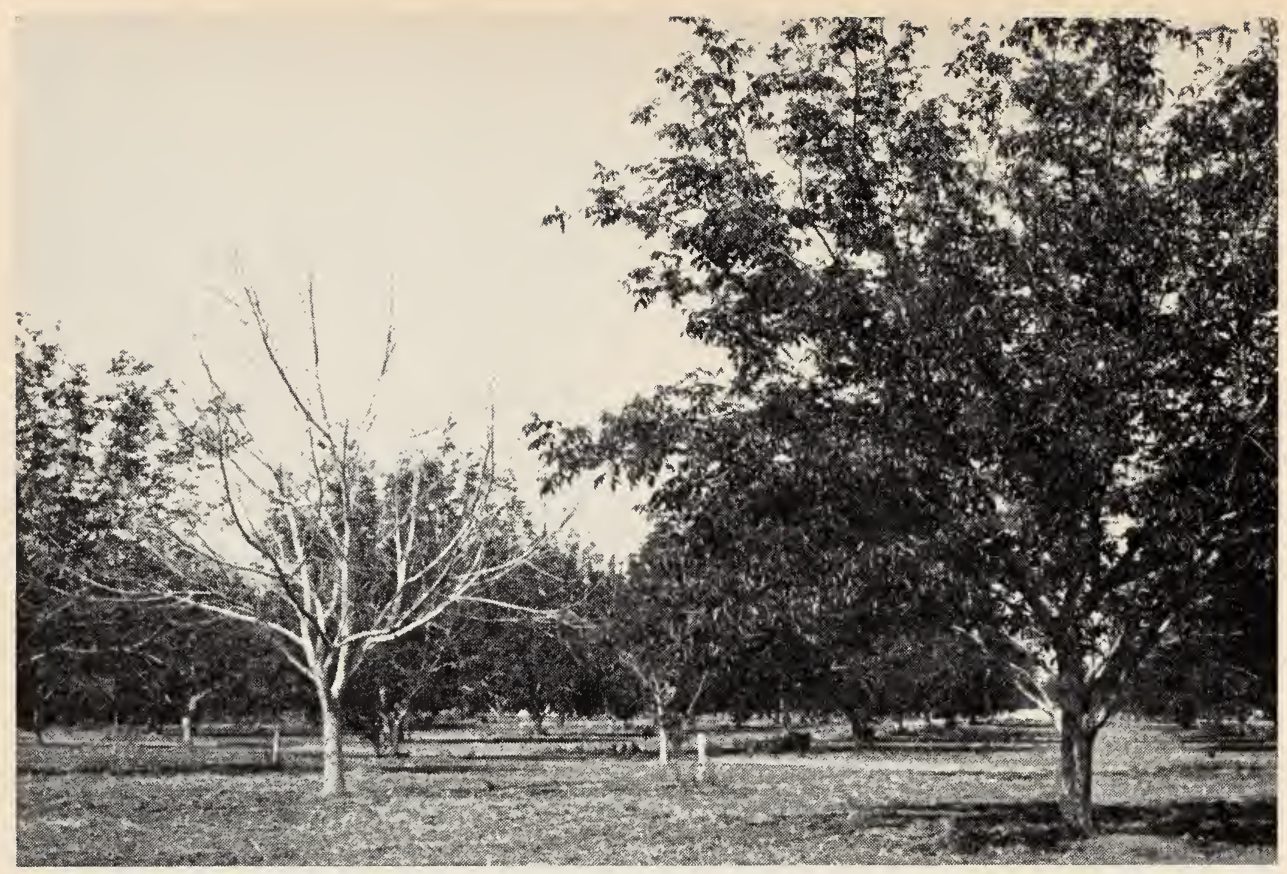

Fig. 18. Left: Eureka walnut tree. Right: Placentia walnut. Photographed on May 9, 1935, after a warm winter near Los Angeles.

Franquette and Mayette will show some delay in starting after even the coldest winters in southern California, and their starting is greatly delayed, sometimes up to July, after the warmest winters. Eureka, Blackmer, Concord, and Payne, also, are injuriously delayed after warm winters in southern California, Payne considerably less than the others.

After most winters, trees of all these varieties, with the possible exception of Payne, start later in southern California than in northern California, much later after the warmest winters. For example, by May 9, 1935, at Redding and Davis, Franquette and Mayette trees had leaves one-half grown, Payne, Blackmer, and Eureka had leaves full grown, all branches of all trees in nearly the same stage of development. At the same time in districts of southern California, Franquette and Mayette showed no buds breaking, Eureka had a few scattered leaves (fig. 18), some just starting, some half grown, Concord had very few buds breaking, Payne had no leaves more than half grown, and Blackmer leaves were only about 10 per cent of full size. In southern California, except on Blackmer, not nearly so many buds were growing as in northern California. The chilling was enough to permit growth in some buds but not in others on the same tree; if chilling had been ample, as it was in northern California, buds on all trees in the same planting would have started approximately together. At this time, trees of Placentia (fig. 18) had leaves developed about as far and nearly as evenly as leaves on Eureka and Payne at Redding and Davis. However, in some especially warm districts free from fogs even Placentia and other southern California varieties were still nearly bare of leaves. There had, of course, been more warm spring weather in southern California than at Davis or at Redding, and trees such as the fig, with little or no chilling requirement, were more advanced in southern than in northern California.

Although the southern California varieties have short chilling requirements, 
there is not always enough cold weather in some districts to cause the buds to open satisfactorily. In fact, the crop in the southern part of the state has been reduced greatly after some especially warm winters. This reduction was due in part to dropping of very small fruits after they had grown slightly from flowers that opened very late. Probably many of these fruits were from flowers that had never been pollinated; the pollen may all have been shed before the pistils on the last shoots to grow were ready for it. Crop re- duction also came from failure of many buds to grow after the warmest winters.

In figure 19 the crop in southern California counties for each year from 1917 to 1936 is shown in millions of pounds by the black bars. Each bar crossed with diagonal lines shows the mean temperature for December, January, and February preceding the crop indicated by the black bar to its right. Since nearly all the crop in those counties is from Santa Barbara soft-shell seedlings and varieties, any large reduction must be due to an

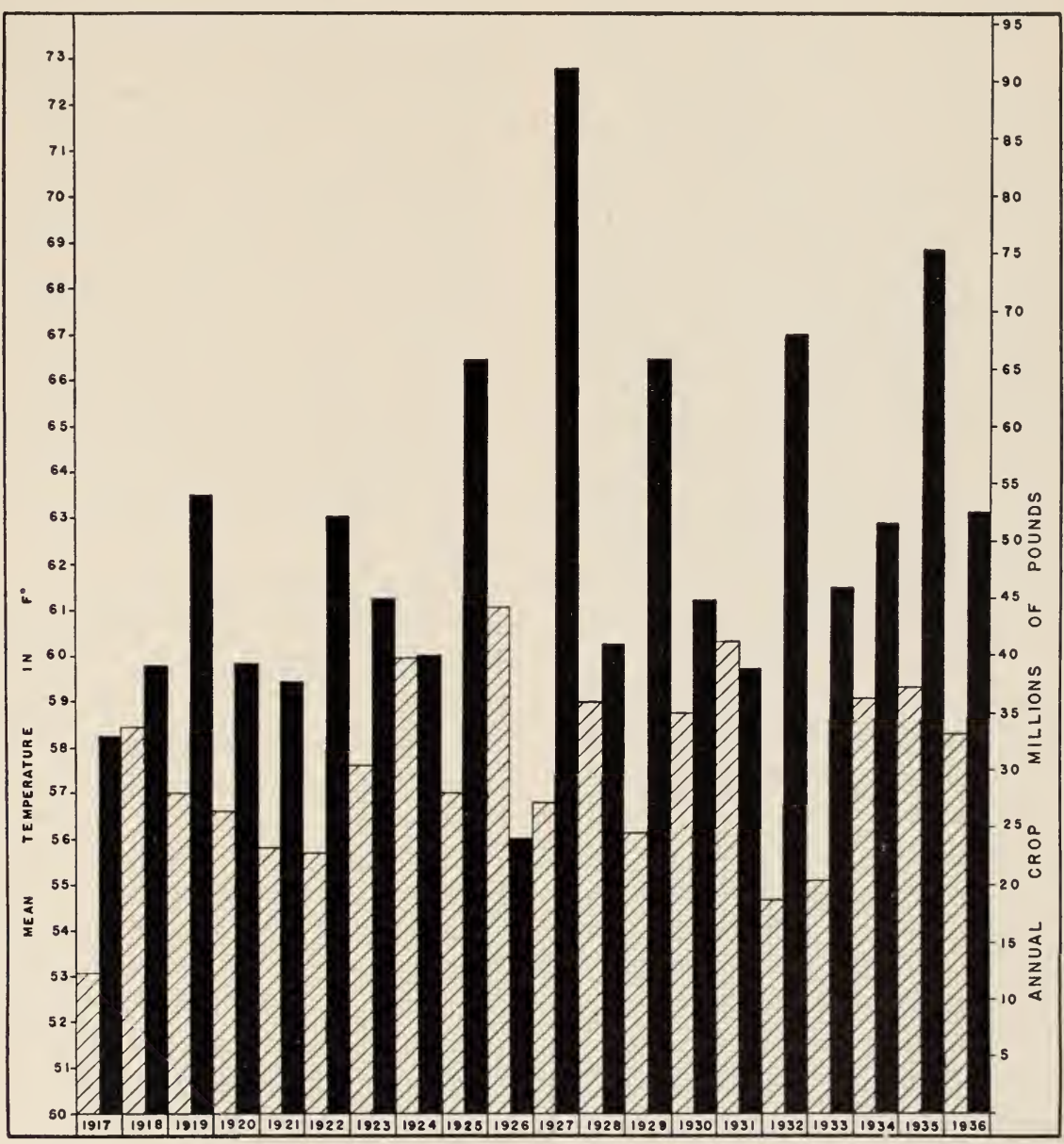

Fig. 19. Black bars: walnut crops, orchard run, in southern California counties. White bars with diagonal lines: mean temperatures, in degrees above $50^{\circ} \mathrm{F}$, for December, January, and February; each white bar gives the temperature for the winter preceding the crop indicated by the black bar to its right. 
influence that affects those varieties. The smallest crop, that of 1926, followed the warmest winter. The crops of 1924, 1928, 1930, 1931, and 1934 were also reduced considerably by the preceding warm winters. The small crop in 1933, after a good winter for chilling, was caused by a spring frost.

For some reason the crop of 1935 was not greatly reduced by the rather warm winter preceding it. Female flowers of the walnut are borne at the ends of small shoots. Buds which produce these shoots are not shed in warm winters, but many remain dormant. Buds two years old or older (as with those of peach trees) seem not to require so much chilling as oneyear-old buds before they will grow. All small shoots, even those which start after the first shoots have been killed by frost, tend to have flowers. Possibly in many orchards in southern California a considerable part of the crop of 1935 was from buds formed in 1933 that had remained dormant in 1934, following another warm winter. We have no accurate observations concerning this problem, however. The crop of 1931 does not seem to have been increased in this way, although many buds had remained dormant in the spring of 1930, which followed another warm winter. The winter preceding the crop of 1931, however, was warmer than the winter preceding the crop of 1935. It may have been too warm even for old buds to grow normally in spring.

The excellent crop of 1927 was preceded by a mean temperature for December, January, and February, at Los Angeles, of $56.7^{\circ} \mathrm{F}, 4.3^{\circ}$ below that for the same months preceding the very small crop of 1926. The mean temperature for these months in Los Angeles preceding the spring of 1937 was $53.9^{\circ}$. In the spring of 1937 on trees of the southern California varieties nearly all buds on the twigs, lateral as well as terminal, grew. In other words, crop reductions were due to winters only $3^{\circ}$ to $7^{\circ}$ warmer than winters with chilling enough for unimpeded bud opening in spring.

In concluding that the light crops in some years were due to the warmer winters preceding, we are, of course, not dependent upon data in figure 19 alone. Workers in the College of Agriculture visited the orchards each spring and observed the delayed starting or the failure of most of the buds to grow, as well as the light setting after the warmest winters.

Walnut trees make only moderate response to spraying with DNO, and the spray kills the male flowers, the catkins. Breeding for short chilling requirement does not seem promising for southern California districts; varieties with much shorter chilling requirements than Placentia may suffer as great losses from spring frosts as Placentia suffers from delayed growth after warm winters.

In years when insufficient chilling prevents many of the one-year-old buds from growing, some of the old buds that grow, especially those far down on large branches, make long shoots that hang downward from the weight of their luxuriant foliage and grow so late that they are in danger of being killed by early frosts.

Unlike apple trees, walnut trees are slow to go into the rest period in summer. There are usually several flushes of growth. In midsummer or later, a walnut tree may form terminal buds on all its shoots and remain without growth long enough for an apple or a pear tree to go completely into the rest period; then, later, new growth may start from some of the shoots. This habit permits the walnut tree to grow so late, when temperature and moisture conditions are favorable, that it is in much greater danger from early winter frosts than any of the common deciduous fruit trees.

The California black walnut seems to have a very slight chilling requirement, and the eastern black walnut perhaps less than some varieties of Persian walnuts, such as Franquette. 


\section{BERRIES}

Blackberries and Dewberries. A small number of the northeastern varieties of blackberries have been observed in the state recently. These seem to be delayed a little in starting after the warmest winters in southern California but apparently fruit satisfactorily.

Careful observations of Young (Youngberry) and Boysen vines indicate that they also are delayed in starting after the warmest winters in southern California, but that they eventually produce an abundance of leaves and a good crop. Vines in the shade of evergreen trees during winter, or vines lying on the ground shaded by their own leaves, start 10 days to 2 weeks earlier than vines exposed to the sun during the winter months.

Currants. The common European currant seems to do a little better than most varieties of gooseberries in the San Francisco Bay area. The Cherry variety fruits rather well in sections where the winters are a little colder and foggier than in Berkeley. In such districts on hillsides above the densest winter fogs, plants are observed to start growth in spring a little later than plants on lower ground, but they eventually make good growth and bear well. There is not enough experience with other varieties to give evidence of how they would behave in such localities.

In southern California, currants, like gooseberries, do not start growth nor blossom satisfactorily after the warmest winters except at rather high elevations too far from the ocean for the summers to be cool and humid enough for currants.

Gooseberries. At least some of the varieties of European gooseberries, Ribes grossularia, start very weakly after any but the coldest winters in Berkeley. In the part above the winter fogs, only a few buds or none at all start on Chautauqua and Portage after the warmest winters.
Several other European varieties and Poorman, a hybrid between an American species and a European variety, also start weakly in spring because of lack of winter chilling. In sections where there is a little more winter chilling than in Berkeley but where the summers are cool and rather humid, there have apparently been fairly satisfactory results with Oregon Champion, which is probably a hybrid between American and European gooseberries.

In southern California, gooseberries start satisfactorily in spring only at rather high elevations, where it is usually too dry for them to do well in summer.

Raspberries. In sunny positions above the winter fogs in Berkeley, all the buds on Cuthbert red raspberry canes often fail to open in spring. This seems to be due to the warm winters, but observations have not been extensive enough to give conclusive evidence. In southern California, even after the winter of 193637 , with its unusual amount of chilling, Cuthbert red raspberry and Munger black raspberry started earlier in shady places than in places exposed to the sun during the winter months. After warm winters, these varieties fail to bear satisfactory crops. Most other varieties show some delay in growth.

Strawberries. There is some evidence that strawberry plants sometimes go into a slight rest period and require a little chilling before their buds will grow freely. Flowering of the plants is influenced more by day length and growing temperature than by rest-breaking temperatures. Short daylight periods are necessary for flower induction of some varieties but plants of some of these, such as Marshall, will flower throughout the year, including the long summer days, in districts where the temperature is low in summer-about $60^{\circ} \mathrm{F}$.*

* Hartmann, H. T. The influence of temperature on photoperiodic response of several strawberry varieties grown under controlled environmental conditions. Amer. Soc. Hort. Sci. Proc. 50:243-45. 1947. 


\section{CONTENTS}

I. The rest period in deciduous orchards $\ldots \ldots \ldots \ldots \ldots \ldots \ldots \ldots \ldots \ldots \ldots$

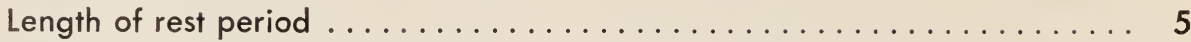

Probable cause of rest period ....................... 6

Function of rest period .......................... 7

Treatments that help break the rest period ................. 9

Exposing to chemicals ....................... 9

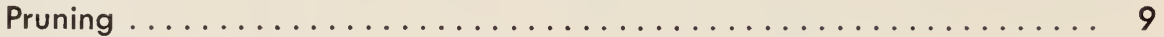

Spraying ................................ 9

Breeding varieties tolerant of mild winters . . . . . . . . . . . 10

II. The importance of winter chilling . . . . . . . . . . . . . . . . 10

Local influences on effectiveness of chilling ............... 11

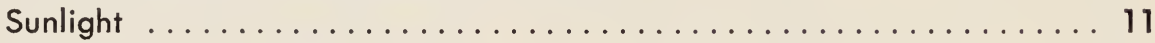

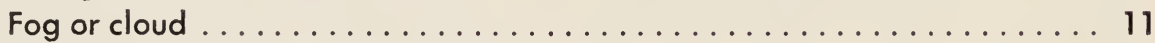

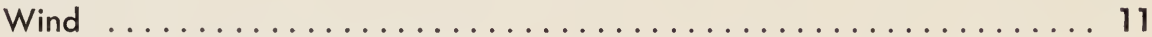

Vegetative condition in autumn...................... 11

Attempting to predict spring growth and flowering $\ldots \ldots \ldots \ldots \ldots \ldots$

III. Winter chilling in some parts of California . . . . . . . . . . . . . . . 13

IV. Chilling requirements of the different deciduous orchard species . . . . . . 18

Fruits .................................... 18

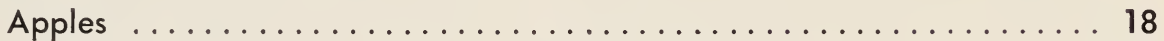

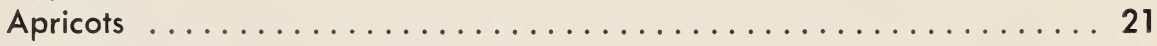

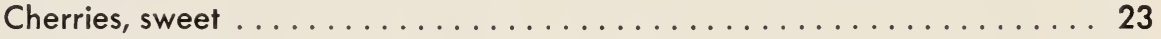

Cherries, sour ................................ 24

Cherries, China . . . . . . . . . . . . . . . . . . . . . . . . . . . . 24

Figs .................................. 24

Grapes, vinifera (Old World) . . . . . . . . . . . . . . . . 25

Grapes, labrusca (slipskin, American) . . . . . . . . . . . . . . . . 25

Grapes, other ................................. 25

Nectarines ... . . . . . . . . . . . . . . . . . . . . . . . . . . 25

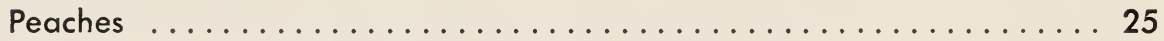

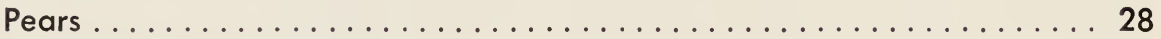

Persimmons ... . . . . . . . . . . . . . . . . . . . . . . . . . . 29

Plums, American . . . . . . . . . . . . . . . . . . . . . 30

Plums, Damson ............................. 30

Plums and prunes, domestica . . . . . . . . . . . . . . 30

Plums, Oriental (Japanese) . . . . . . . . . . . . . . . . . . . . 30

Quinces .................................... 31

Nuts .......................................... 31

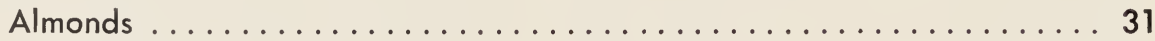

Chestnuts ................................... 31

Filberts, or hazelnuts ........................... 33

Walnuts ................................... 33

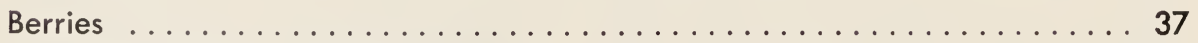

Blackberries and dewberries .................... 37

Currants ... . . . . . . . . . . . . . . . . . . . . . . . . . . 37

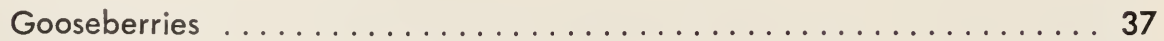

Raspberries ... . . . . . . . . . . . . . . . . . . . . . . . 37

Strawberries ... . . . . . . . . . . . . . . . . . . . . . . 37 
In order that the information in our publications may be more intelligible, it is sometimes necessary to use trade names of products and equipment rather than complicated descriptive or chemical identifications. In so doing, it is unavoidable in some cases that similar products which are on the market under other trade names may not be cited. No endorsement of named products is intended nor is criticism implied of similar products which are not mentioned. 


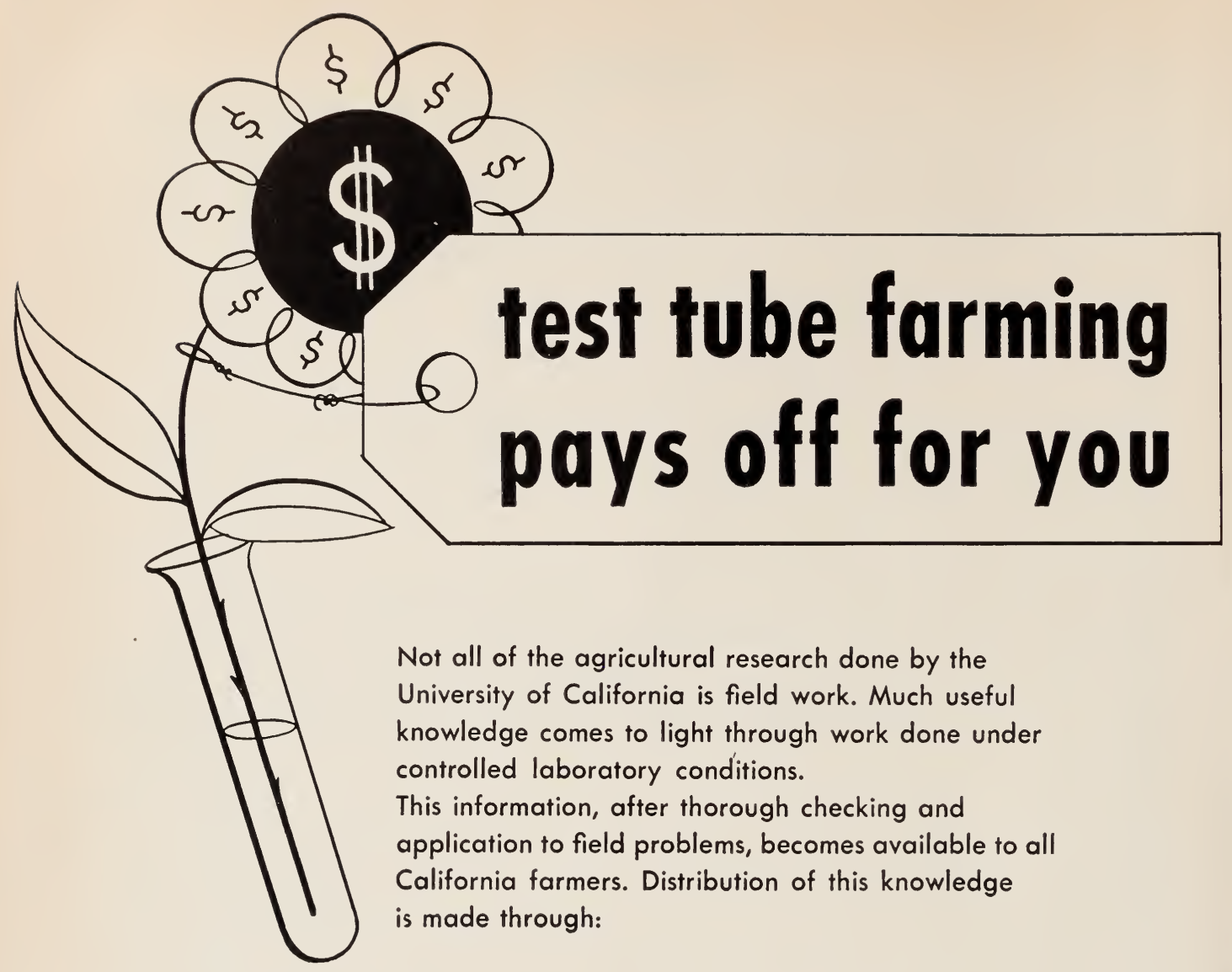

\section{LITERATURE:}

Circulars, bulletins, lithoprints, and leaflets by specialists are available free. These publications cover many subjects relating to agriculture in the state. For a catalog of this literature write to the Office of Agricultural Publications, 22 Giannini Hall, University of California, Berkeley 4.

\section{COUNTY FARM ADVISORS:}

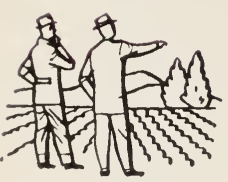

Farm Advisors are agricultural specialists with a background

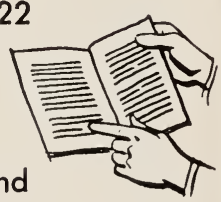
of practical knowledge. They serve 52 counties throughout the state and their mission is to help farmers work out their problems. Get to know your Farm Advisor-take advantage of his services.

\section{MAIL INQUIRIES:}

If you prefer to put your questions in a letter, mail them to the Public Service Office of the College of Agriculture, University of California, either at Berkeley or at Davis. Your problem will be referred to the person or department best able to give you the exact information you need.

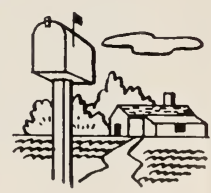

